\title{
READING BETWEEN THE BARS: EXPLORING THE REPRESENTATION OF YOUNG ADULTS WITH INCARCERATED PARENTS IN TEXT LITERATURE
}

\author{
by \\ Carissa Parsons, Bachelor of Social Work \\ Ryerson University, 2019 \\ An MRP \\ presented to Ryerson University \\ in partial fulfillment of the \\ requirements for the degree of \\ Master of Social Work \\ in the program of \\ Social Work \\ Toronto, Ontario, Canada, 2020 \\ (C) Carissa Parsons, 2020
}




\section{AUTHOR'S DECLARATION FOR ELECTRONIC SUBMISSION OF A MRP}

I hereby declare that I am the sole author of this MRP. This is a true copy of the MRP, including any required final revisions.

I authorize Ryerson University to lend this MRP to other institutions or individuals for the purpose of scholarly research.

I further authorize Ryerson University to reproduce this MRP by photocopying or by other means, in total or in part, at the request of other institutions or individuals for the purpose of scholarly research.

I understand that my MRP may be made electronically available to the public. 


\title{
READING BETWEEN THE BARS: EXPLORING THE REPRESENTATION OF YOUNG ADULTS WITH INCARCERATED PARENTS IN TEXT LITERATURE
}

\author{
Master of Social Work, 2020 \\ Carissa Parsons \\ Social Work \\ Ryerson University
}

\begin{abstract}
The purpose of this paper is to examine and explore how young adults with incarcerated parents are represented in text-based literature. Although a plethora of research has recently emerged regarding the effects of imprisonment on the social, psychological, economic, and spiritual wellbeing of the family unit, young adults are rarely acknowledged. As a result, existing research appears informative, revolutionary and predictive; however, it instead contributes to creating the profile of a deviant and socially reclusive young adult with adverse life outcomes. This study is a critical reflexive literature analysis that incorporates a narrative methodology to gain insight into the representation of young adults between the ages of 17 and 25 . With a selection of themes observed from the textual evidence, this study recommends three ways to humanize young adults with confined parents by building upon their personal narratives.
\end{abstract}

Keywords: young adults, parental incarceration, critical reflexive, narrative 


\section{ACKNOWLEDGEMENTS}

I wish to show my gratitude to those who made this MRP a possibility and helped foster both my thoughts and process. To my family and friends who tolerated my blood, sweat and tears (plenty of tears), I simply cannot thank each of you enough. 


\section{DEDICATION}

For the young adults impacted by parental incarceration, thank you for both the stories you share and those you keep to yourself. Both have the power to change the world. 


\section{TABLE OF CONTENTS}

AUTHOR'S DECLARATION....

ii

ABSTRACT

iii

ACKNOWLEDGEMENTS

iv

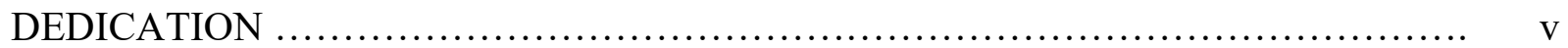

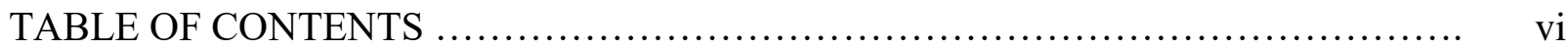

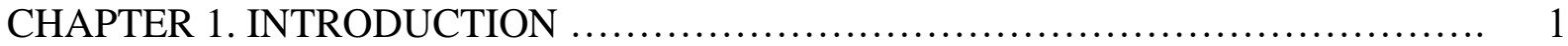

CHAPTER 2. LITERATURE REVIEW ....................................... 3

CHAPTER 3. THEORETICAL FRAMEWORKS ................................ 18

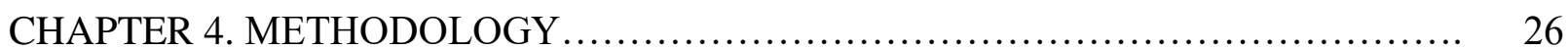

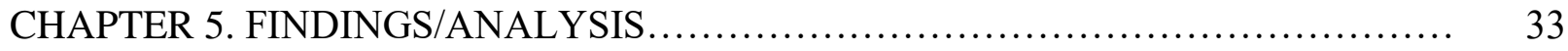

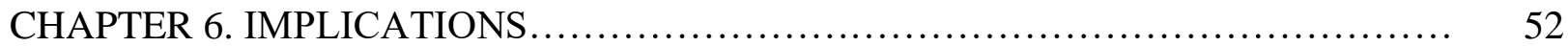

CHAPTER 7. CONCLUSION ............................................. 55

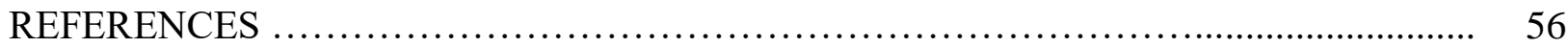




\section{Chapter 1. Introduction}

Researchers around the globe have been continuously attempting to conceptualize mass incarceration, specifically within the United States. They have been unable to pinpoint a single cause or determinant for these record numbers however, they have contributed to a vast array of knowledge regarding the impact of imprisonment on families (O'Hear, 2017). Canada's incarceration rate is not comparable to the United States' in scale, yet the phenomenon is still apparent and prevalent (Hardy, 2018). For many families impacted by a parent's incarceration, within a Canadian context, their experiences feel overlooked and underserviced. I am only aware of this overwhelming feeling of erasure because I have lived and endured it myself.

Often, when researchers discuss the impacts of incarceration, they do not identify their relation to this vulnerable population. A lack of being clear about social location allows professionals who have no emotional ties to the community to evade responsibility and benefit from it while running the risk of exploiting it. I am not implying that all researchers need to have confined parents, but it is essential to be mindful of why we conduct particular research and what has allowed us the ability to do so. For this reason, I am adamant on remaining transparent in this paper because I have the immense privilege and duty to bring light to my community. I believe it is essential to acknowledge my positionality before engaging in analysis. I am a white, cisgender woman, able-bodied, pansexual, a European settler, someone who has access to higher education, and has a previously imprisoned parent.

In some instances, I am seen by people in this community as an outsider identity due to my social work education (Blix, 2015). I understand the role that social workers have in intersecting with my community; through the Children's Aid Society, policing, the criminal justice system, courtrooms among many other services. However, because of my father's direct 
ties to those currently or previously incarcerated, I am often identified by society as an insider. When people from outside of my community become aware of my father's confinement, they sometimes equate me to his behaviours.

Being conscious of my connection to this topic, I am narrowing my focus to exploring the question of how young adults between the ages of 17 and 25 who have or had an incarcerated parent are represented in text-based literature. Before I begin a critical reflexive analysis that explores themes regarding this representation, I review existing writing to gain insight into parental incarceration as a whole. My personal experiences partly influenced my decision to study young adults, but through conducting a literature review I have discovered a noticeable gap. Significant amounts of literature emphasized the impacts on parents, school-age children, and teens, but young adult children seem to get excluded from the discussion. This absence of consideration deeply concerned me; therefore, I wanted to include young adults' personal stories to spark a conversation and advocate for their needs.

Before dissecting literature, it is beneficial to define the language utilized throughout this critical reflexive analysis. The social construction of language can be incredibly impactful, and it can liberate some while stigmatizing others (Witkin, 2012). Therefore, I explain terminologies before their usage in this paper for the sake of clarity. The terms "incarceration", "confinement" or "imprisonment" express a period in which an individual must remain in either jail or prison on a provincial or federal level. The term "parent" will encompass; birth parents, stepparents, adopted parents, legal guardians, or primary caregivers. These terms intend to be neutral and inclusive to those impacted by parental incarceration. Although the phrase "incarcerated parent", "confined parent" or "imprisoned parent" may be used frequently, the reader must remain mindful that this is not to imply that we should define a parent by their period of separation. 


\section{Chapter 2. Literature Review}

A thematic analysis of scholarly and peer-reviewed literature produced between the years of 1991 and 2020 reveals a staggering absence of information on young adults with incarcerated parents. As a result of minimal relevant content, this literature review has expanded to include any research or article on children with confined parents. Chapter 2 presents five themes that frequently emerge in the literature discussing this population. These themes provide insight into dominant theoretical frameworks often implemented by social service professionals while they are engaging with my community. Following each of these five themes, I will provide critiques and potential alternatives.

The first theme of Chapter 2 is the prominent reliance on risks and need factors when working with both young adults and their parent(s). Following this, topic two will discuss the subjectivity of resiliency and what it means for social service professionals, as opposed to those with living with parental confinement. The third theme brings attention to both propensity scores and remedial approaches which have gained significant traction in the fields of criminology and criminal justice. Theme four acknowledges attachment theory and ecological systems theory and considers their widescale applicability through a variety of disciplines. I conclude topic five by assessing the concepts of stigma, spoiled identity, labelling, stigma management and how they impact young adults with incarcerated parents.

\section{Theme 1. Risks and Needs Assessment Instruments}

Risks and needs assessment instruments have deeply ingrained roots in a variety of professions within and beyond social services, especially when working with young adults. One of the most commonly recognized and understood risks and needs assessment instruments is the Risk-Needs-Responsivity (RNR) model (Andrews, Bonta, \& Wormith, 2011). RNR was 
originally an intake assessment, conducted when prisoners arrived at a facility to determine their likelihood of engaging in violence during their incarceration (James, 2018). This assessment was based on prison staff's personal and professional opinions and designated where confined individuals should be placed in the prison to limit the "risk" of security and safety breaches (James, 2018). RNR has since evolved as a tool to determine an individual's risk of recidivism upon release and what needs must be met to reduce their chance of reoffending (James, 2018).

The incarcerated person is then classified as low risk, medium risk, or high risk and will be placed in corresponding rehabilitative programs (James, 2018). The RNR model proposes that those with the highest risk should receive the most support while those with low risk should have minimal access or none at all (James, 2018). RNR within an environment such as a prison or a clinical mental health setting tends to emphasize binary and traditionalist approaches to addressing social issues and psychological needs. For example, a prison social worker might link depression to biological and genetic components within the brain and DNA, and their approach may be medications to reduce recidivism (Carodet, 1992). Grassroots organizations are more likely to use bottom-up assessment instruments that account for localized, environmental risks that predict future incarceration (Bettencourt, 2019).

The theme of risk and needs assessment instruments first became apparent in Phillips and O'Brien's (2012) study which gathered data from a 2007 pilot project at a community organization in Chicago. The pilot sought to intervene in the lives of children with incarcerated parents in the hopes of interrupting what they as label "risk pathways" through individualized support (Philips \& O'Brien, 2012). Philips and O'Brien's (2012) community-level research incorporates risk and need assessments from both clinical and grass-root approaches to theorize adverse child outcomes. The outcomes that are deemed harmful by the social work researchers 
are; emotional and behavioural problems, substance abuse, rejection of law and authority, and academic failure (Philips \& O'Brien, 2012).

The first subcategory of risks and needs they assess for is a parent risk factor which includes; substance abuse, mental illness, domestic violence, minimal educational attainment, and family risk factors (Philips \& O'Brien, 2012). The second category of risks/needs is family risk factors which encompass; single-parent households, poverty, changes in caregiving, changes in living accommodation and inadequate care (Philips \& O’Brien, 2012). Most risks, however, become visible through the process of risks/needs assessments implemented within correctional facilities upon imprisonment (RNR) (Mignon \& Ransford, 2012). Under the guise of assessment instruments, (Philips \& O'Brien, 2012) state that the most consistent research conclusion in literature is that children of incarcerated parents experience more risk factors and have more needs than the general population (Philips \& O'Brien, 2012). This concept was also seen in (Dallaire, 2007; Hanington, 2020; Murray \& Farrington, 2008).

When reviewing literature regarding the theme of needs and risks assessment instruments, two notable concerns appear. One concern is that the individuals creating, informing, and using these instruments are rarely the same people impacted by them. Instead, devices such as RNR are rooted in the personal beliefs and values of staff members who may have no lived experience with these risks and needs. Young adults are rarely included in the process of risks and needs; therefore, what they need for support is assumed (Mignon \& Ransford, 2012). Also, when RNR is utilized in the process of a prison intake, the parent's needs are based on a risk system, and they may be denied supports that are beneficial to them and their families (Mignon \& Ransford, 2012). 
A potential suggestion for implementing risks and needs assessment instruments when working with young adults is to ensure they are also involved in informing, creating, and evaluating the devices. Informing may resemble professionals explaining to young adults and their parents what their instruments entail, what risks their services focus on, and what needs are expected to be met. Creating and evaluating could encompass social services and prisons working alongside young adults when they are establishing instruments and programming. Inclusion ensures that workers are moving beyond their perceptions and understandings of what classifies a risk or need. These assessments should be continuously evaluated perhaps through written evaluations upon the completion of services to see if their needs met and what other risks could be addressed in future programming.

\section{Theme 2. Resiliency}

Helping professions are interested in reducing human suffering; for some this may look like recognizing the resiliency of those with imprisoned parents. Someone being resilient means they can "bounce back in the face of adversity and to go on to live functional lives with a sense of wellbeing" (Turner, 2001, p. 441). Some well-recognized qualities of those deemed to be resilient include; a sense of humour, having a direction or life mission, intellect, insightfulness, ability to adapt, independence, self-efficacy, talent and skill (Werner \& Smith, 1992, as cited in Turner, 2001, p. 442). Resiliency builds upon risks and needs factors because it implies that despite all the barriers and hardships one faces, they can avoid adverse outcomes through internal strength (Turner, 2001). Unlike risks and needs factors which attempt to predict unpleasant life outcomes, being resilient and having positive life encounters such as a supportive role model can alter their wellbeing (Turner, 2001). 
Resiliency also draws on a variety of other theoretical origins, including cognitive behavioural therapy (Beck, 1976) and social learning theory (Bandura, 1977). Professionals who favour a cognitive behavioural framing of resiliency believe our internalized thoughts and views of the world impact our behaviours (Turner, 2001). To manage negative actions and thoughts, social workers may intervene by helping a child with an incarcerated parent to acknowledge and improve these patterns (Beck, Rush \& Shaw, 1979). For those who gravitate to social learning theory to understand resiliency, they view a child's behaviours as a non-stop intersecting relationship between their cognitions, actions and environmental factors (Bandura, 1977). Those implementing social learning theory to their profession theorize that individuals learn by interacting with others and observing how others interact with them (Bandura, 1977).

Although resiliency can represent youth in a way that is dynamic and considerate of their strength, it also has significant complications. My first concern is that resiliency is subjective and will look different to professionals and the children of incarcerated parents. For one professional, their client obtaining a college diploma may represent being resilient. At the same time, a child with a confined parent such as myself may see getting out of bed in the morning on a bad day as an accomplishment. It is important to note that perceptions of success can be rooted in our personal beliefs and values.

Ossefort-Russell's (2018) article pertains to the experience of grief and loss, however, I believe it has extreme relevancy to the physical and emotional separation/loss of a parent. Ossefort-Russell (2018) discusses how our body and nervous systems respond when we experience distressing events. When our bodies naturally react to bad things happening through anger, exhaustion, avoidance, or overt sadness for "too long", society judges us and shames us. As a result, individuals such as children of incarcerated parents can internalize these societal 
messages, and they may start to wonder if they are hurting because they are not resilient enough (Ossefort-Russell, 2018).

Regardless of one's resiliency, they are still being bombarded by physical fight or flight reactions that indicate they are in danger (Ossefort-Russell, 2018). Responding negatively to traumatizing events is completely normal and to not feel powerful is as valid as "overcoming adversity" (Ossefort-Russell, 2018). In addition, not feeling resilient and experiencing all aspects of human pain and suffering can also have the capability to lead to personal processing and healing (Ossenfort-Russell, 2018). It is also important to note that for young adults who appear to be "successful" or "strong" they may be feeling grief and loss in private due to societal stigma. For many individuals impacted by this phenomenon continuing to live life as "normal" and pushing aside pain may be their only option as they don't have the support or resources to be anything but resilient.

\section{Theme 3. Propensity Scores \& Remedial/Alternative Approaches}

Researchers in the fields of criminology and criminal justice have been focused on the intergenerational impact of incarceration and the ability to predict future deviance (Miller \& Barnes, 2015). Propensity score framework has allowed professionals in the criminology and criminal justice domain to compare external determinants in instances where randomized trials are unethical or challenging to calculate the results (Clemens et al., 2015). For example, it would be inhumane to incarcerate one category of parents arbitrarily and force their children to feel the repercussions of their confinement. Propensity score permits researchers to view and contrast between existing wide-scale data and the general population that is not impacted by a given phenomenon (Cochran et al., 2018). Cochran et al. (2018) implement propensity scores to build upon statistics that suggests youth with incarcerated parents cope with profound amounts of 
micro and macro-level shame, psychological strain, and stigmatization. They were able to use this information to determine a causal relationship between this population and connecting with peer networks that are anti-social (Cochran et al., 2018).

Criminal justice and criminology have taken into consideration how to combat parental incarceration and intergenerational imprisonment using remedial theoretical approaches. Intergenerational imprisonment is the repeated process of incarceration throughout generations (Dallaire et al., 2010). Intergenerational imprisonment is especially prevalent for Canada's Indigenous Peoples as a result of colonization, and trauma that has been endured and passed down for generations (Hanington, 2020). This compacted victimization and oppression has led to a significant presence of Indigenous Peoples within Canada's correctional facilities. Research related to this overrepresentation has been steadily growing and has recently emphasized Indigenous youth that have become intertwined with the criminal justice system.

Remedial approaches stray from the traditional routine of crime and harsh punishment and instead localize support for specific individuals to discourage future criminal behaviours (Lynch, 2011). Latimer and Foss' (2004) qualitative study used a Snapshot method which reports the number of Indigenous youths incarcerated in Canada on any day in a year. They choose Snapshots from 2000 to 2003 in collaboration with the collected data they received through a remedial Sharing Circle method. This method involves an Elder from an Indigenous community passing around a talking rock to foster conversation regarding their personal experiences with incarceration.

The researchers discovered that the youth reported extreme benefits from remedial programs implemented at their facility. The programs they engaged in included sweat lodges, pow-wows, Indigenous language courses, dancing and drums, and traditional singing, among 
many other activities. Also, they discovered the youth seemed eager and interested to learn about Indigenous culture and spirituality. Many of the individuals stated that they thought access to this remedial programming opposed to probation would reduce their chances of reoffending. This research was fundamental because the criminology and criminal justice field tend to neglect the overwhelming amount of Indigenous youth in corrections.

Although the field of criminology and criminal justice have relied on frameworks such as propensity scores, remedial/alternative approaches, they still have severe limitations. As a result, prison abolitionists have placed increased scrutiny and pressure on the criminology and criminal justice fields to humanize and improve services for prisoners (Mayrl, 2013). A plethora of research exists, but little legitimate change occurs because the funding from the research often allows these programs to run. Once studies have ceased, their perhaps beneficial supports disappear, and researchers have given the perception that they are making progressive change, while over-researched participants get forgotten (Neufeld et al., 2019).

My review of criminology and criminal justice literature also reveals an underlying fixation on pathologizing and a problem-focused approach. Reflecting on this overemphasis of negative attributes and outcomes for individuals raises the question of how this potentially impacts the reputation and wellbeing of young adults with incarcerated parents. The field has a tremendous opportunity to reform their information by prioritizing remedial tactics within jails and prisons. Remedial programming can aid in altering conventional and cynical narratives, especially in criminology and criminal justice by drawing on the strengths of both young adults and their parents. Perhaps by recognizing and building stories and research on the power within young adults, the sector of criminology and criminal justice can contribute to influencing a compassionate narrative alongside us. 


\section{Theme 4. Attachment Theory \& Ecological Systems Theory}

Professionals from a number of varying disciplines have gathered and contributed a wealth of knowledge from attachment theory. Attachment theory "focuses on the quality of the parent-child interactions that contribute to children's close relationships and wellbeing across the life span" (Bowley, 1982, as cited in Poehlmann-Tynan et al., 2017, p. 389). Attachment theory also examines how children respond to the absence of (or separation from) their parent in instances such as confinement (Poehlmann-Tynan et al., 2017). Studies centred around attachment theory have shown evidence that parental incarceration not only leads to a poor connection between the parent and child but between the child and their social networks (Miller \& Barnes, 2015). Researchers from domains such as family studies and social work have also recently proposed solutions on how to address the consequences of weak attachments between confined parents and their children.

As previously discussed, Miller and Barnes' (2015) longitudinal study also examines the attachment between individuals under the age of 18 and their fathers who are experiencing incarceration. Their review was able to pinpoint a causal connection between weak attachments and adverse life outcomes related to social wellbeing, educational attainment, economic prosperity, among many other effects. Although their research compares data from Canada, the United Kingdom, and Germany, the growing numbers in the United States allowed them to provide service suggestions for healthy attachment in an American context. They articulated the need for rehabilitation, treatment and re-entry programs to incorporate families in the process (Miller and Barnes, 2015). Miller and Barnes (2015) imply that secure attachments before the age of 18 can improve living conditions in later life. 
Hanington (2020) mimics the benefits and downfalls of insecure attachments and suggests community-based alternatives to confinement. This substitution would advocate for parents to remain in the home (when appropriate and safe) to ensure the child is supported and the process is normalized. Community-based programming could potentially minimize the harm to the connection between a child and their parent because the parent no longer is uprooted from the child's immediate surroundings. Other researchers have put into consideration how to enhance attachments within the context of correctional institution settings.

Poehlmann-Tynan et al. (2017) research findings proposed that when young children visit parents at correctional institutions, they are often fearful of the procedures and routines that are in place. Facilities often require long wait times, and there is a lack of physical contact with parents which can cause separation anxiety; the location of the jail or prison may not be near the family and child, causing long commutes. Children may also be fearful of the dogs that search the individuals attempting to visit the incarcerated individual (Poehlmann-Tynan, 2017). The Baby Elmo Program is one effort that the criminal justice system has made in improving attachments.

The Baby Elmo Project is a low-cost parenting class and play-based therapy provided to teen-fathers within juvenile justice institutions (Barr et al., 2011). The Baby Elmo Project tries to create connections between the young parents and their infants. Traditionally prisons have been attempting to generate attachment by offering parenting classes, but these classes are not always applicable based on personal circumstances and cultural differences in child-rearing (Barr et al., 2011). The intention behind Baby Elmo Program is to provide specific services to individuals and their abilities while having the child present to put theory into application. The belief is that 
with strong bonds, children will have a better quality of life and more durable, healthier relationships with others (Barr et al., 2011).

Numerous professions and research domains around the globe employ ecological systems theory to comprehend the impact of incarceration on families. Arditti (2005) uses their article to build upon ecologically sensitive practice by incorporating Bronfenbrenner's (1977) systematic approach for theorizing development. When Bronfenbrenner (1977) introduced ecological systems theory, its intention was to be utilized by human development researchers. Since its creation, this theory has also received significant contributions from mental health and psychology-related professions and tends to remain centred in these domains (Eriksson, Ghazinour \& Hammarström, 2018). It is important to note that ecological theory and attachment theory share overlap in how they understand environmental influences and components; therefore, both may sound similar.

Ecological systems theory proposes that children's proximal relationships and interactions (e.g. caregivers or teachers) are systems that can influence their development (Dallaire et al., 2010). The strength of this theory is that it can examine the impact of many systems ranging from structural to micro-level, which allows for a broader understanding of the child's development (Dallaire et al., 2010). This framework can serve beneficial to understanding how an incarcerated parent may have effects on a child, and how the direct environment of prison may cause potential risks to wellbeing (Barr et al., 2011). Ecological system theory examines the child's surrounding supports at this time to consider how they may alter their development and coping abilities (Johnson \& Easterling, 2015). However, this theory moves even further beyond direct influence and takes into account large scale situations that compact development such as; 
poverty, legislative changes, and economic crisis, among many other circumstances that may occur in the same period.

In two separate studies, Poehlmann-Tynan (2005) demonstrated that the caregiving environment children occupy during the period of incarceration is crucial for development, whether that development is positive or negative (As cited in Poehlmann-Tynan et al., 2017). Although their work Attachment in young children with incarcerated fathers specifically focusses on young children and fathers, it is still applicable to understanding the early experiences of young adults. Poehlmann-Tynan et al. (2017) combine both aspects of ecological theory and attachment theory to conceptualize parental incarceration and adverse outcome as a result of confinement. Their work hypothesized two unique ideas, the first being that "sensitive, responsive, and developmentally supportive caregiving in the home would moderate risks associated with current parental incarceration in jail" (Poehlmann-Tynan, 2017, p. 392). The second hypothesis was that children in an ecological setting, such as a prison would mimic the same attachment behaviours as observed within their caregiving environment/home (PoehlmannTynan, 2017).

To ensure that both research predictions explored all aspects of the child's ecological surroundings, the researchers also considered factors such as; the child's age, the family's income, race, length of imprisonment, how frequently the child was able to visit, among many others (Poehlmann-Tynan et al., 2017). In both portions of the study, the researchers discovered that ecological factors, particularly the child's age and the parent's substance consumption drastically impacted their attachment (Poehlmann-Tynan et al., 2017). Older children demonstrated a more secure attachment with their parents than younger children, and children who have parents with substance concerns had more insecure attachments (Poehlmann-Tynan et 
al., 2017). When observing if children mimicked attachments displayed in their homes, Poehlmann-Tynan (2017) revealed that those who witnessed crimes or arrests also experienced insecure attachments to their caregivers. The research also uncovered that their first hypothesis was accurate and the second was relatively precise, as children with more stimulating caregiving environments were more likely to establish secure attachments with their father (Poehlmann et al., 2017).

A limitation of ecological systems and attachment theory is that they attempt to account for every potential influence in the child's life. Therefore, it is difficult to determine that one specific event or a series of events were the root cause of harmful or unhealthy development. In addition, Bronfenbrenner's original definition has become diluted by modern researchers who place significant emphasis on the external environment of children and teens (Tudge, 2016). Bronfenbrenner stated that "In ecological research, the properties of the person and of the environment, the structure of environmental settings, and the processes taking place within and between them must be viewed as interdependent and analyzed in system terms" (Tudge, 2016, p.428). For both theories to be utilized to capacity, they must include all aspects of Brofenfenner's work to aid in acknowledging an individual's resilience and coping mechanisms, in collaboration with their external stimuli.

\section{Theme 5. Stigma, Spoiled Identity, Labelling \& Stigma Management}

The idea of stigma and labelling in literature first became visible in Dallaire, Ciccone and Wilson's (2010) study titled Teachers experiences with and expectations of children with incarcerated parents. Their qualitative study interviewed 30 teachers to understand why children with incarcerated parents have an increased risk of academic failure (Dallaire et al., 2010). Their research found that the majority of participants had witnessed their fellow teachers treating or 
discussing these students with less expectation than others (Dallaire et al., 2010). The researchers involved in this study believe that this stigma and labelling may contribute to the academic difficulties that many children and teens experience (Dallaire et al., 2010).

Luther's (2016) study Stigma Management among Children of Incarcerated Parents conceptualizes stigma by utilizing Irving Goffman's theory of "spoiled identity." This framework states that incarcerated individuals are stigmatized and labelled as deviant, immoral, and by association alone their children inherit this "spoiled identity" (Luther, 2016). Researchers Cochran, Siennick, and Mears (2018) build upon Foster and Hagan's (2016) paper by assessing in school surveys with 90,000 respondents. Using this data, they compared and contrasted the personal experiences of children with and without incarcerated parents (Cochran et al., 2018). What they observed was that children with incarcerated parents had fewer friendships, fewer social supports, less engagement in school activities, and had more conflict with teachers (Cochran et al., 2018). What these findings may indicate is that these children do indeed experience some degree of increased exposure to stigma, labelling, and social exclusion.

Luther's (2014) study analyzes how 32 college students manage "spoiled identity". The researchers used open-ended interview questions which led them to three themes of management; 1 . separating themselves from their parent 2 . viewing their parent as an example 3 . framing the incarceration as a positive experience. Luther (2016) observed that these selfidentified stigma management techniques allowed young adults to create prosocial identities that differ from their parent. The idea of stigma management is seen again in Johnson and Easterling's (2015) study titled Coping with Confinement: Adolescents' Experiences with Parental Incarceration. In this study, ten youth between the ages of 11-17 who had experienced parental incarceration were asked to guide semi-structured interviews. The interviews intended to 
map out how young adults manage or cope with their parent's imprisonment. A few of the observed methods of management were; deidentifying with their parent, avoiding the discussion of incarceration, normalizing the incarceration, focusing on things they can control, and going to therapy (Johnson \& Easterling, 2015).

Although literature rooted in stigma, spoiled identity, labelling and stigma management provide the opportunity to listen to the narratives of young adults more intently, they also contain significant errors. One limitation is that stigma and labelling related theories, perhaps unintentionally imply that children, youth and young adults will experience stigma. However, many individuals state not experiencing any form of discrimination or "spoiled identity" (Luther, 2016). The term spoiled identity in itself is inherently stigmatizing for young adults and their parents; it designates parents as spoiled while it indicates that their children should expect to be as well. Sociological approaches must expand beyond framing parents as negative individuals and relocate the onus for managing stigma from youth to society as a whole. 


\section{Chapter 3. Theoretical Frameworks}

The purpose of this study is to reveal common themes/narratives that exist within textbased research and articles regarding young adults with confined parents. Often my community is referred to as the "unrecognized victims of crime"; therefore, it is also necessary to use their unique narratives to reframe these conceptions (Coulthard, 2010). Traditional victims of crime face: theft of property, bodily or property damage, violence, hate crimes, and psychological abuse; children of incarcerated parents suffer similarly but are uniquely associated with the crimes as well. (Coulthard, 2010). These children pay with their futures, psychological wellbeing, social standing, self-image, safety, security, and their homes (Bernstein, 2005). Therefore, it is critical to consider the perceptions of their experience from an anti-oppressive framework built upon with postmodernism and social constructionism. I will remain mindful of my reflexivity while analyzing these perceptions.

\section{Anti-Oppressive Practice}

Anti-Oppressive Practice (AOP) is an overarching umbrella framework which draws influence from several theories including; "anti-racism, whiteness studies, postmodernism, and feminism and queer theory" (Barnoff \& Moffatt, 2007). AOP emerged in the 1970s as a way of understanding, analyzing, and addressing systematic, social, and structural inequities (Dominelli, as cited in Zhang, 2018; Yee \& Wagner, 2013). AOP encourages users to seek their social location within social systems through the utilization of Kimberlé Crenshaw's (1989) theoretical framework, intersectionality (Zhang, 2018). Crenshaw's (1989) work was intended to consider the way race and gender intersect but has since evolved to study the complexity of social/power relations such as; race, gender, sexuality, class, sexual orientation, and disability, among others (Zhang, 2018). 
Without deeper consideration it's easy to classify this paper as inherently AOP in nature; however, I use AOP with great caution. The issue I identify with AOP is that, in the academic world and particularly in the field of social work, it is presented as the only "just" approach to conducting practice (Zhang, 2018). AOP, upon first glance seems to guarantee practitioners a way to liberate marginalized communities from oppressive societal structures (Zhang, 2018). To question or reconsider AOP is often seen by mainstream social service professionals as a direct opposition of social justice values, and therefore it is rarely critiqued (Zhang, 2018). I have the desire to move away from an overreliance on AOP and consider how I as a researcher can build upon it while highlighting other frameworks.

Due to its multidiscipline applicability, the exact definition of AOP can be challenging to pinpoint and is frequently the topic of debate. This elusiveness likely contributes to its growing popularity in academia and practice. Still, the alarming growth in usage makes me, and other professionals' question if AOP has simply become a jargon term used to demonstrate performative "wokeness". In a growing neoliberal state, which prioritizes worker productivity and individualism, organizations are eager to hire employees that highly skilled and sufficient (Yee \& Wagner, 2013). To meet these corporate requirements, universities and colleges, especially those with social work programs, rely on AOP as a way to teach students how to "do" social work (Zhang, 2018).

To prepare undergraduate and graduate social work students, schools must adapt to the increasing privatization of social services (Zhang, 2018). A central tenant of AOP is that the person using the framework must understand the historical positionality of any group in society that experiences marginalization (Yee \& Wagner, 2013). This generalized knowledge draws interest away from specific intersectional social injustices and treats AOP as a theory opposed to 
a framework (Zhang, 2018). As a result, AOP within academia and research becomes something that students must master in order to be competitive and "valuable" within the labour market (Yee \& Wagner, 2013). I often find myself falling into the well-disguised trap that is AOP because, in the social work profession and education, it is viewed as "normative" (Zhang, 2018). My intention is not to entirely disregard AOP; to deny the potential benefits is a mastery mindset that implies that I know best. I also recognize that AOP is the dominant framework used to approach young adults with incarcerated parents and that to avoid it is to ignore the undeniable reality of mainstream practice. I instead want to build upon the valuable foundation of AOP using a more in-depth analysis of it, specifically through postmodern and social constructionism theories. I also want to incorporate the reflexive self to avoid the essentializing of the textual narratives that will be used for the purpose of this paper.

\section{Postmodernism}

Science-led explanations of the world gained popularity in the 18th century, commonly referred to as the Enlightenment period. The Enlightenment was named such to indicate separation and rejection of the dark Catholic church in favour of light, modern, universality, and evidence-based knowledge (Witkin, 2012). "Modernism" is considered to have arisen during this time frame. Modernism was supposed to liberate humans from the restriction and dictatorship of the church, but after WWII, postmodernists emerged, claiming this objective was not met (Witkin, 2012). Postmodernists contended that seeking an ultimate truth had oppressed individuals much like Catholicism, by limiting subjective ways of knowing (Witkin, 2012).

Postmodernists instead advocated for an endless number of truths and ways of perception. Although to modernists, they appeared to have minimal guidance, scholars have been able to identify several key components that define postmodernism. These include; examining 
meaning through language, opposing static identities, rejection of all-encompassing narratives, and denying that knowledge can be objective and free of power and dominant values (Witkin, 2012). These values led to the early formation and growth of social constructionism, especially within the social work profession. Challenging the dominant powers in society and encouraging alternative discourses are critical components in social work practice. Therefore, postmodernism will be vital to this research to expand and change common societal perceptions of young adults with incarcerated parents.

\section{Social Constructionism}

For humans to survive and flourish, they must draw on aid from their relationships to other individuals; these relationships are believed to be the central tenet of social constructionism (Witkin, 2012). Social constructionism studies these connections and interactions to theorize the world and its associated privileges and oppressions (Parton \& Byrne, 2000). This framework implies that societal and cultural influences enforce humanity's perception of the world and deviates from reductionist frameworks of conceptualization (Pietroni, 1995). Also, this lens states that since early civilization, groups around the globe created sets of rules and consequences for those who ignored "socially acceptable behaviours" (Durrant \& Ward, 2015). Reductionism has stemmed from science-based practices such as biology, psychology and chemistry to measure, rationalize, and quantify the causes of non-normative behaviour (DeLisi \& Conis, 2018).

Constructionism does not encourage researchers to seek one universal and scientific truth as a valid way of knowing. Instead, it advocates for varying truths that are contested and constructed by humans depending on factors such as; personal experiences, location, time, and history (Arribas-Ayllon \& Walkerdine, 2008). This theoretical approach also encourages 
researchers to consider that societal truth is often fabricated and legitimized by those who are in positions of power to maintain control of the masses (Moffatt, 1999 a). However, it is essential to acknowledge that power is not maintained or held by one person; power is fluid, widely practised, and alters depending on the relationship (Moffatt, 1999 a). This ideology provides an alternative way of perceiving young adults with incarcerated parents. It contests that public perceptions of these individuals are not factual or evidence-based and are instead a result of power dynamics.

Despite having several recognizable traits, social constructionism can be elusive and challenging to define. By creating a concrete definition for constructionism, researchers are opposing its mission by limiting it to one understanding or construct (Witkin, 2012). Therefore, those conducting studies often avoid incorporating it into their work for fear of not including observable evidence. Instead, they may rely on evidence-based methods to limit the chance of being challenged and to instead appeal to readers and scholars. My study can draw strength from this framework because experiencing the incarceration of a parent positively or negatively will not apply to all young adults. My father's incarceration was not a positive experience but I know many young adults who have close, happy bonds with their parents and this is a reminder that I must remain open to critique and be willing to learn from other perspectives.

Existing narratives for children of incarcerated parents are often produced by mainstream discourses that view society as needing to be protected. This narrative prioritizes the societal fear of criminals, gangs, and controlled substances over rehabilitation and support (Warde, 2013). As a result, children of incarcerated parents are viewed as by-products of illegal conduct and behaviours. Utilizing a social constructionist framework alters the perception of these youth as a statistic of crime. Drawing away from strictly number-based data in favour of personal stories 
and recommendations will hopefully demonstrate that these common narratives get built on a victim complex and hidden prejudices.

Postmodernism and social constructionism should serve as a reminder to all researchers, journalists, readers, students, and professionals of relevant fields that young adults with confined parents are not a unified identity. Through statistics and observation, our life outcomes or experiences may sound similar. On a systematic level, we may endure overarching oppressions. These commonalities, however, do not mean we are the same. Although having a static, constructed identity can be beneficial in both advocating for our unique needs and seeking public recognition in our minds and our stories; we are the experts. We all have a truth regarding the experience of our parent's incarceration. Through our acknowledgement of other's stories and truths, we can learn to take power back from societal narratives that speak for us.

\section{The Critical Reflexive Self}

When discussing the reflexive self, it is essential to note that there are two distinct ways of understanding this theory. The initial way is by examining Schön's (1983) work which opposes the notion of the production of knowledge requiring technicalities and rationalization to be deemed legitimate (Moffatt, 2019). Instead, Schön (1983) advocates for constant shifts in paradigms to match the shifting nature of the professional world (Moffatt, 2019). Another way to comprehended reflexive is by expanding on and exceeding the properties of self-reflection. Selfreflection "is a process of thinking about and exploring an issue, which is triggered by an experience" (Lam et al., 2007, p. 93).

Self-reflection exercises one's ability to; recognize an issue, reflect on the way they felt, how they responded, and how they would address the situation in hindsight using professional practices. Self-reflection can be helpful for those who are new to understanding their behaviours 
and responses; however, it is not nearly enough for in-depth practitioners and studiers. In a sense, self-reflection implies that the researcher is independent and can remain objective regarding their professional experiences (Lam et al., 2007). Both postmodernism and social constructionism argue that researchers cannot remove themselves from their work. All professional theories, including "unbiased" empirical tactics, are rooted in hierarchies and power relationships.

\section{Schön and the Reflexive Self}

Within both postmodernism and social constructionism, there is a need to be aware and critical of all relationships and ways of knowing. This includes the researcher's perceptions of the world and its configurations. Reflexive practice encourages social work professionals, educators, and those engaged in the production of information to understand that they can never truly be neutral and value-free in this process (Miehls \& Moffatt, 2000). Schön (1983) states that a reflexive practice asks us to acknowledge and be aware of how we construct realities, and what theoretical frames of consciousness we have available to us as a result of said realities. However, Schön's (1983) paper prescribes to humanist ideals by viewing those in practice as having static or fixed autonomy, even when their viewpoints and frameworks change (Moffatt, 2019).

Although Schön's (1983) approach to the reflexive self in practice has established the necessary groundwork, for this research, it is critical to expand on this concept. Reflexivity in this paper reminds me throughout my process as a researcher that my perception of parental incarceration as a young adult is rooted in my own lived experience. Reflexivity is adamant that I and researchers alike must consider that our perception of reality is created and maintained through our environment, culture, and interactions (Witkin, 2012). The period during which my father was confined is my truth, and by telling my story, I am making meaning for myself and occasionally others (Witkin, 2012). By moving beyond self-reflection, individuals like myself 
are acknowledging that our introspection is not harmless. Instead, it is the process of continually interrogating our deeply entrenched values and attempting to understand what we are doing.

I cannot reach out to the individuals included in my analysis to clarify the purpose and emotions behind their words. Therefore, I have a great responsibility to present their narratives in a way that is dutiful and worthwhile; this is why I have chosen to create themes as opposed to assuming specific meaning. This requires an immense amount of accountability and selfreflexivity, and regardless of my intentions, I must remain open to criticism that my interpretation may be inaccurate. In best practice, I will be drawing on self-reflexivity as a theoretical approach to remain as transparent and understanding as possible. 


\section{Chapter 4. Methodology}

Due to implications associated with the COVID-19 pandemic, the method of this research transitioned from narrative interviews to a critical reflexive approach to inquiry. I believe this methodology is the most appropriate way to mimic my original intentions without conducting inperson research. This approach will involve inspecting and analyzing text-based literature (what this entails will be touched upon later in this chapter). In addition to examining literature, I will reflect and narrate my own experience with parental incarceration in relation to the some of the concepts that are touched upon. I hope that through critical reflexivity I can build upon the themes and recommendations in a way that places me in the context of parental incarceration both as a researcher and as a human (Fook, 1999).

There are two primary ways of gathering information and data for research; these include qualitative and quantitative methods (Faulkner \& Faulkner, 2016). Intending to simplify these methods; a qualitative approach to research is through language, observations, and in-depth descriptions (Faulkner \& Faulkner, 2016). Quantitative chooses to instead focus on adding to the wealth of knowledge that already exists using numerical evidence (Faulkner \& Faulkner, 2016). Quantitative methodology approaches research from a belief that the ultimate truth can be achieved through fact-based evidence (Denzin \& Giardina, 2016). In seeking objective truth, quantitative research fails to acknowledge that all "facts" are rooted in value, theories and power relations (Denzin \& Giardina, 2016).

Quantitative data scratches the surface of parental incarceration by attempting to conceptualize general themes of structural inequality (Charmaz, 2017). These broad themes gained through statistical evidence can aid in policy changes and large-scale advocacy (Charmaz, 2017). As a result of statistical domination in helping professions section, one of the critical 
reflexive analysis incorporates both qualitative and quantitative data. Section two will focus on qualitative data within a reflexive narrative and postmodern lens. This allows for immeasurable meaning and permits the individual telling their story to control and reframe how they interpret the world (Witkin, 2012).

\section{Narrative Inquiry}

Narrative inquiry simplified is the study of how humans come to understand and explain the world around them (Connelly \& Clandinin, 1990). Humans have used telling stories and narratives as a way of passing on meaning and teachings since the beginning of time; this is still prominent amongst Canada's Indigenous population (Baskin, 2016). Cree educator Charles Lanigan (1998) states "Stories incorporate several possible explanations for phenomena, allowing listeners to creatively expand their thinking process so that each problem they encounter in life can be viewed from a variety of angles" (Lanigan, 1998, as cited in Baskin, 2016, p.337). Storytelling has occurred through a variety of mediums including; oral history, art, dancing, textual writing, film, and poetry, among many other forms (Connelly \& Clandinin, 1990.) Narrative inquiry can highlight an individual's experiences, but it has also been used as a means of explaining the formation of groups and communities (Connelly \& Clandinin, 1990). Narrative inquiry allows ordinary everyday people to take power back by redefining their perception of the world through their expressions.

Creswell (2013) states that narrative research tends to rely on several defining features when utilizing this methodology. The first feature is that researchers collect stories or narratives regarding their participants, and they may work in collaboration with the individual to reveal a story through their interaction together (Creswell, 2013). Once a story is revealed whether it is an oral story, a visual story, or textual, it may shed light on identities and how individuals visualize 
themselves (Creswell, 2013). Another defining feature is that in many instances, researchers will order the stories being shared into chronological order so they can be analyzed (Creswell, 2013). The final aspect of narrative research is that it can occur in various places or situations; in the instance of this research that situation would be parental incarceration (Creswell, 2013).

\section{Method of Selection for Literature}

To find textual literature, I first determined what criteria are necessary to be included in this critical analysis. Due to a lack of literature on young adults, criteria to be included in the research was relatively relaxed. Although there are a few pieces that target children, the majority of texts had to discuss young adults between the ages of 17-25. My searches included keywords such as; young adults with incarcerated parents, experiences of young adults with incarcerated parents, and services for young adults with incarcerated parents 17-25. These primary searches allowed me to expand resources by utilizing the reference sections of relevant literature.

All literature had to be text-based, meaning it was written and not in the form of documentaries, songs, art, or photography. Text-based criteria led me to search for words such as; stories of young adults with incarcerated, poems of young adults with incarcerated parents, and diaries of young adults with incarcerated parents. The final requirement for inclusion in this analysis was that the literature must be from the years between 1991 and 2020. This restriction intended to create a time frame just before young adults being born till present time to examine if themes altered over that period. My findings indicated that they remained relatively the same over nearly 30 years.

For this research, the analysis/reflection is broken into two distinct sections; the first being themes in text-based research and articles, which encompasses; research studies in scholarly journals, research essays, data analyses online newspaper articles, websites, and online 
magazine articles. The purpose of section one (Figure \# 1- Figure \# 4) is to reveal three narrative(s) that emerged throughout text-based media. The second section is a critical analysis that focuses on textual narratives derived from young adults impacted by parental incarceration to provide ways to counteract the narratives of part one positively. This portion of the analysis included; narrative research studies, websites, online blogs, online articles, online newspaper articles, and online magazine articles, all of which are condensed into four recommendations.

Figures \#1-4 includes every piece of literature found in Chapter 5. Findings and Analysis. Figures \#1-4 all include the name of the piece examined, the main focus of that text, where it originated from, the type of document it is, and who created it. Figure \#1. explores comparative narratives in text literature about young adults with incarcerated parents. Figure \#2. highlights literature overemphasis on adverse life outcomes when researching and discussing my community. Figure \#3. overviews the difficulties in providing support to young adults as a result of conflicting social, psychological, physical, and economic supports. Figure \#4. includes texts created by young adults to present recommendations for future researchers and writers focusing on this population.

Figure \# 1: Theme 1: Comparative Narratives

\begin{tabular}{|l|l|l|l|l|}
\hline Article Title & $\begin{array}{l}\text { Sex, Parental } \\
\text { Incarceration, and } \\
\text { Violence } \\
\text { Perpetuation } \\
\text { Among a Sample of } \\
\text { Young Adults }\end{array}$ & $\begin{array}{l}\text { Health Care Use } \\
\text { and Health } \\
\text { Behaviours Among } \\
\text { Young Adults with a } \\
\text { History of Parental } \\
\text { Incarceration }\end{array}$ & $\begin{array}{l}\text { Parents in prison } \\
\text { and the lasting } \\
\text { health effects on } \\
\text { children }\end{array}$ & $\begin{array}{l}\text { The Effects of } \\
\text { Parental } \\
\text { Imprisonment on } \\
\text { Children }\end{array}$ \\
\hline Focus of Text & $\begin{array}{l}\text { Comparing violence } \\
\text { rates between young } \\
\text { adults with and } \\
\text { without incarcerated } \\
\text { parents }\end{array}$ & $\begin{array}{l}\text { Comparing health- } \\
\text { care use and } \\
\text { unhealthy } \\
\text { behaviours between } \\
\text { young adults with } \\
\text { and without } \\
\text { incarcerated parents }\end{array}$ & $\begin{array}{l}\text { Comparing long } \\
\text { term health effects } \\
\text { between children } \\
\text { with and children } \\
\text { without incarcerated } \\
\text { parents }\end{array}$ & $\begin{array}{l}\text { Finding a link } \\
\text { between parental } \\
\text { incarceration and } \\
\text { adverse life } \\
\text { outcomes by } \\
\text { analyzing existing } \\
\text { data }\end{array}$ \\
\hline Source & $\begin{array}{l}\text { Jediatrics Journal } \\
\text { Interpersonal } \\
\text { Violence }\end{array}$ & $\begin{array}{l}\text { Journalist's } \\
\text { Resource }\end{array}$ & $\begin{array}{l}\text { Crime and Justice } \\
\text { Journal }\end{array}$ \\
\hline
\end{tabular}




\begin{tabular}{|l|l|l|l|l|}
\hline Media Type & $\begin{array}{l}\text { Online Textual } \\
\text { Research Study }\end{array}$ & $\begin{array}{l}\text { Online Textual } \\
\text { Research Study }\end{array}$ & $\begin{array}{l}\text { Online Textual } \\
\text { News Article }\end{array}$ & $\begin{array}{l}\text { Online Textual } \\
\text { Research Essay }\end{array}$ \\
\hline Author Type & Researchers & Researchers & Journalists & Researchers \\
\hline
\end{tabular}

Figure \#2: Theme 2: Adverse Life Outcomes

\begin{tabular}{|l|l|l|l|l|}
\hline $\begin{array}{l}\text { Article } \\
\text { Title }\end{array}$ & $\begin{array}{l}\text { The Effect of } \\
\text { Maternal } \\
\text { Incarceration on } \\
\text { Adult Offspring } \\
\text { Involvement in the } \\
\text { Criminal Justice } \\
\text { System }\end{array}$ & $\begin{array}{l}\text { Incarcerated } \\
\text { Mothers and } \\
\text { Fathers: } A \\
\text { Comparison of Risks } \\
\text { for Children and } \\
\text { Families }\end{array}$ & $\begin{array}{l}\text { Children face lifelong } \\
\text { struggles if their } \\
\text { parents are } \\
\text { incarcerated, study } \\
\text { details }\end{array}$ & $\begin{array}{l}\text { The Antisocial } \\
\text { Behavior of the } \\
\text { Adolescent Children of } \\
\text { Incarcerated Parents: } \\
\text { A Developmental } \\
\text { Perspective }\end{array}$ \\
\hline $\begin{array}{l}\text { Focus of } \\
\text { Text }\end{array}$ & $\begin{array}{l}\text { Link between } \\
\text { maternal } \\
\text { incarceration and } \\
\text { future incarceration }\end{array}$ & $\begin{array}{l}\text { Analyzing the } \\
\text { predictive power of } \\
\text { parental } \\
\text { incarceration }\end{array}$ & $\begin{array}{l}\text { Demonstrating adverse } \\
\text { life outcomes for } \\
\text { children with } \\
\text { incarcerated parents }\end{array}$ & $\begin{array}{l}\text { Connection between } \\
\text { parental incarceration } \\
\text { and anti-social } \\
\text { behaviours }\end{array}$ \\
\hline $\begin{array}{l}\text { Source } \\
\text { Media } \\
\text { Type }\end{array}$ & $\begin{array}{l}\text { Journal of Criminal } \\
\text { Justice }\end{array}$ & $\begin{array}{l}\text { Family Relations } \\
\text { Journal }\end{array}$ & Journalist's Resource & $\begin{array}{l}\text { Office of the Assistant } \\
\text { Secretary for Planning } \\
\text { and Evaluation }\end{array}$ \\
\hline $\begin{array}{l}\text { Author } \\
\text { Type }\end{array}$ & Researchers & Researcher & Journalists & $\begin{array}{l}\text { Online Textual } \\
\text { Research Project }\end{array}$ \\
\hline
\end{tabular}

\begin{tabular}{|c|c|c|c|c|}
\hline $\begin{array}{l}\text { Article } \\
\text { Title }\end{array}$ & $\begin{array}{l}\text { Identifying as a } \\
\text { Troublemaker/Partier } \\
\text { : The Influence of } \\
\text { Parental } \\
\text { Incarceration and } \\
\text { Emotional } \\
\text { Independence }\end{array}$ & $\begin{array}{l}\text { With parents in } \\
\text { prison, kids at risk } \\
\text { for lasting } \\
\text { psychiatric } \\
\text { problems }\end{array}$ & $\begin{array}{l}\text { Parental Incarceration } \\
\text { and Gender-Based } \\
\text { Risks for Increased } \\
\text { Body Mass Index: } \\
\text { Evidence From the } \\
\text { National Longitudinal } \\
\text { Study of Adolescent } \\
\text { Health in the United } \\
\text { States }\end{array}$ & $\begin{array}{l}\text { The Impact of Parental } \\
\text { Incarceration on the } \\
\text { Physical and Mental } \\
\text { Health of Young Adults }\end{array}$ \\
\hline $\begin{array}{l}\text { Focus of } \\
\text { Text }\end{array}$ & $\begin{array}{l}\text { Examining young } \\
\text { adults with } \\
\text { incarcerated parents } \\
\text { who identify as } \\
\text { "troublemakers" or } \\
\text { "partiers" }\end{array}$ & $\begin{array}{l}\text { Psychiatrics } \\
\text { concerns of young } \\
\text { adults with } \\
\text { incarcerated parents }\end{array}$ & $\begin{array}{l}\text { Analyzing the link } \\
\text { between females with } \\
\text { incarcerated parents } \\
\text { and likelihood of } \\
\text { obesity }\end{array}$ & $\begin{array}{l}\text { Outlining the impacts } \\
\text { of parental } \\
\text { incarceration on young } \\
\text { adults' physical and } \\
\text { psychological } \\
\text { wellbeing }\end{array}$ \\
\hline Source & $\begin{array}{l}\text { Journal of Child and } \\
\text { Family Studies }\end{array}$ & Reuters News U.S & $\begin{array}{l}\text { American Journal of } \\
\text { Epidemiology }\end{array}$ & Pediatrics Journal \\
\hline $\begin{array}{l}\text { Media } \\
\text { Type }\end{array}$ & $\begin{array}{l}\text { Online Textual } \\
\text { Research Study }\end{array}$ & $\begin{array}{l}\text { Online Textual } \\
\text { News Article }\end{array}$ & $\begin{array}{l}\text { Online Textual } \\
\text { Research Study }\end{array}$ & $\begin{array}{l}\text { Online Textual } \\
\text { Research Study }\end{array}$ \\
\hline
\end{tabular}




\begin{tabular}{|l|l|l|l|l|}
\hline $\begin{array}{l}\text { Author } \\
\text { Type }\end{array}$ & Researchers & Journalist & Researchers & Researchers \\
\hline
\end{tabular}

Figure \# 3: Theme 3: Conflicting Supports

\begin{tabular}{|l|l|l|l|l|}
\hline Article Title & $\begin{array}{l}\text { Parental } \\
\text { Incarceration and } \\
\text { Intergenerational } \\
\text { Transfers to Young } \\
\text { Adults }\end{array}$ & $\begin{array}{l}\text { The Baby Elmo } \\
\text { Program: } \\
\text { Improving teen } \\
\text { father-child } \\
\text { interactions within } \\
\text { juvenile justice } \\
\text { facilities }\end{array}$ & $\begin{array}{l}\text { Children of } \\
\text { Incarcerated } \\
\text { Parents: } \\
\text { Developmental } \\
\text { Trajectories of } \\
\text { Externalizing } \\
\text { Behavior Across } \\
\text { Adolescence }\end{array}$ & $\begin{array}{l}\text { Stigma management } \\
\text { among Children of } \\
\text { Incarcerated } \\
\text { Parents }\end{array}$ \\
\hline Focus of Text & $\begin{array}{l}\text { Examining } \\
\text { intergenerational } \\
\text { effects of } \\
\text { incarceration }\end{array}$ & $\begin{array}{l}\text { Determining } \\
\text { potential benefits of } \\
\text { the Baby Elmo } \\
\text { Program }\end{array}$ & $\begin{array}{l}\text { Pinpointing } 4 \\
\text { externalizing } \\
\text { behaviour } \\
\text { trajectories that } \\
\text { impact youth in } \\
\text { later life }\end{array}$ & $\begin{array}{l}\text { Examining how } \\
\text { youth manage } \\
\text { stigma associated } \\
\text { with their parent's } \\
\text { incarceration }\end{array}$ \\
\hline Source & $\begin{array}{l}\text { Journal of Family } \\
\text { Issues }\end{array}$ & $\begin{array}{l}\text { Children and Youth } \\
\text { Services Review } \\
\text { and Behaviour } \\
\text { Journal }\end{array}$ & $\begin{array}{l}\text { Deviant Behavior } \\
\text { Journal }\end{array}$ \\
\hline Media Type & $\begin{array}{l}\text { Online Textual } \\
\text { Research Study }\end{array}$ & $\begin{array}{l}\text { Online Textual } \\
\text { Research Study }\end{array}$ & $\begin{array}{l}\text { Online Textual } \\
\text { Research Study }\end{array}$ & $\begin{array}{l}\text { Online Textual } \\
\text { Research Study }\end{array}$ \\
\hline Author Type & Researcher & Researchers & Researchers & Researcher \\
\hline
\end{tabular}

Figure \#4: Recommendations

\begin{tabular}{|c|c|c|c|c|}
\hline $\begin{array}{l}\text { Article } \\
\text { Title }\end{array}$ & $\begin{array}{l}\text { One professor's fight to } \\
\text { help the children of } \\
\text { incarcerated parents }\end{array}$ & $\begin{array}{l}\text { Stigma } \\
\text { Management } \\
\text { among Children } \\
\text { of Incarcerated } \\
\text { Parents }\end{array}$ & $\begin{array}{l}\text { What It's Like to Have } \\
\text { an Incarcerated } \\
\text { Parent }\end{array}$ & $\begin{array}{l}\text { The Long Shadow Cast } \\
\text { By A Parent's } \\
\text { Incarceration. }\end{array}$ \\
\hline $\begin{array}{l}\text { Focus of } \\
\text { Text }\end{array}$ & $\begin{array}{l}\text { Outlining shortcomings } \\
\text { of traditional research } \\
\text { and information on } \\
\text { individuals with } \\
\text { incarcerate parents } \\
\text { using the opinions of } \\
\text { young adults with } \\
\text { incarcerated parents }\end{array}$ & $\begin{array}{l}\text { How college } \\
\text { student manage } \\
\text { stigma associated } \\
\text { with having an } \\
\text { incarcerated } \\
\text { parent }\end{array}$ & $\begin{array}{l}\text { Raising awareness } \\
\text { regarding the } \\
\text { experience of having } \\
\text { an incarcerated parent }\end{array}$ & $\begin{array}{l}\text { How a parent's } \\
\text { incarceration can } \\
\text { impact a child into } \\
\text { adulthood particularly } \\
\text { through stigma }\end{array}$ \\
\hline Source & Medium.com & $\begin{array}{l}\text { Deviant Behavior } \\
\text { Journal }\end{array}$ & TeenVogue.com & wbur.com \\
\hline $\begin{array}{l}\text { Media } \\
\text { Type }\end{array}$ & $\begin{array}{l}\text { Online Textual News } \\
\text { Article }\end{array}$ & $\begin{array}{l}\text { Online Textual } \\
\text { Narrative } \\
\text { Research Study }\end{array}$ & $\begin{array}{l}\text { Online Textual } \\
\text { Magazine Article }\end{array}$ & $\begin{array}{l}\text { Online Textual News } \\
\text { Article }\end{array}$ \\
\hline $\begin{array}{l}\text { Author } \\
\text { Type }\end{array}$ & $\begin{array}{l}\text { Individual with } \\
\text { incarcerated }\end{array}$ & $\begin{array}{l}\text { Researchers using } \\
\text { narratives of }\end{array}$ & $\begin{array}{l}\text { Journalist using } \\
\text { narratives of young } \\
\text { adults directly }\end{array}$ & $\begin{array}{l}\text { Individual with } \\
\text { incarcerated }\end{array}$ \\
\hline
\end{tabular}




\begin{tabular}{|l|l|l|l|l|}
\hline & $\begin{array}{l}\text { parent/researcher/profe } \\
\text { ssor }\end{array}$ & $\begin{array}{l}\text { young adults } \\
\text { directly }\end{array}$ & $\begin{array}{l}\text { parent/researcher/profe } \\
\text { ssor }\end{array}$ \\
\hline
\end{tabular}

Figure \#4: Recommendations Continued

\begin{tabular}{|c|c|c|c|c|c|}
\hline $\begin{array}{l}\text { Artic } \\
\text { le } \\
\text { Title }\end{array}$ & $\begin{array}{l}\text { Coping With } \\
\text { Confinement: } \\
\text { Adolescents' } \\
\text { Experiences With } \\
\text { Parental } \\
\text { Incarceration }\end{array}$ & $\begin{array}{l}\text { The Avary } \\
\text { Blog }\end{array}$ & $\begin{array}{l}\text { Daughters } \\
\text { Beyond } \\
\text { Incarceration- } \\
\text { What we do \& } \\
\text { Our Team }\end{array}$ & $\begin{array}{l}\text { Children of the } \\
\text { Condemned: } \\
\text { Grieving the Loss } \\
\text { of a Father to } \\
\text { Death Row }\end{array}$ & $\begin{array}{l}\text { We can help- } \\
\text { Programs and } \\
\text { Services }\end{array}$ \\
\hline $\begin{array}{l}\text { Focu } \\
\text { s of } \\
\text { Text }\end{array}$ & $\begin{array}{l}\text { Understanding } \\
\text { how young adults } \\
\text { with incarcerated } \\
\text { parents navigate } \\
\text { and cope with } \\
\text { associated } \\
\text { stressors }\end{array}$ & $\begin{array}{l}\text { Stories of } \\
\text { young adults } \\
\text { who } \\
\text { contribute to } \\
\text { Project Avary } \\
\text { through their } \\
\text { volunteer } \\
\text { work and } \\
\text { formal } \\
\text { employment at } \\
\text { the } \\
\text { organization }\end{array}$ & $\begin{array}{l}\text { Information } \\
\text { regarding the } \\
\text { purpose and } \\
\text { mission of the } \\
\text { organization, } \\
\text { and the } \\
\text { founders }\end{array}$ & $\begin{array}{l}\text { Discussing the } \\
\text { stigma and } \\
\text { challenges } \\
\text { associated with } \\
\text { paternal } \\
\text { incarceration } \\
\text { specifically, death } \\
\text { row }\end{array}$ & $\begin{array}{l}\text { Camps for children of } \\
\text { incarcerated parents } \\
\text { provided by the } \\
\text { Elizabeth Fry Society } \\
\text { and young adult } \\
\text { volunteers. }\end{array}$ \\
\hline $\begin{array}{l}\text { Sour } \\
\text { ce } \\
\text { Origi } \\
\text { n }\end{array}$ & $\begin{array}{l}\text { Journal of } \\
\text { Adolescent } \\
\text { Research }\end{array}$ & $\begin{array}{l}\text { Projectavary.o } \\
\text { rg }\end{array}$ & Dbinola.com & $\begin{array}{l}\text { Journal of Death } \\
\text { and Dying }\end{array}$ & $\begin{array}{l}\text { Elizabethfrysocietyof } \\
\text { greatervancouver.ca }\end{array}$ \\
\hline $\begin{array}{l}\text { Medi } \\
\text { a } \\
\text { Type }\end{array}$ & $\begin{array}{l}\text { Online Textual } \\
\text { Narrative } \\
\text { Research Study }\end{array}$ & $\begin{array}{l}\text { Online } \\
\text { Website/ } \\
\text { Textual Blog }\end{array}$ & $\begin{array}{l}\text { Online } \\
\text { Textual } \\
\text { Website }\end{array}$ & $\begin{array}{l}\text { Online Textual } \\
\text { Narrative Research } \\
\text { Study }\end{array}$ & $\begin{array}{l}\text { Online Textual } \\
\text { Website }\end{array}$ \\
\hline $\begin{array}{l}\text { Auth } \\
\text { or } \\
\text { Type }\end{array}$ & $\begin{array}{l}\text { Researchers using } \\
\text { narratives of } \\
\text { young adults } \\
\text { directly }\end{array}$ & $\begin{array}{l}\text { Young } \\
\text { adults/teens } \\
\text { with currently } \\
\text { or previously } \\
\text { incarcerated } \\
\text { parents }\end{array}$ & $\begin{array}{l}\text { Website } \\
\text { curators } \\
\text { building upon } \\
\text { lived } \\
\text { experiences of } \\
\text { organization's } \\
\text { founders }\end{array}$ & $\begin{array}{l}\text { Researchers using } \\
\text { narratives of young } \\
\text { adults directly }\end{array}$ & \\
\hline
\end{tabular}




\section{Chapter 5. Findings and Analysis}

For this section of the research, I have divided the findings into two distinct segments with a series of subsections. Part one focuses on presenting results collected and observed through internet accessible research and mainstream textual media. Researchers and the general public are the primary producers of the information focused on in this section. These findings are condensed into overarching themes and analyzed regarding their potential impact on existing narratives regarding young adults with incarcerated parents. Part two will compile stories and perspectives from young adults and emphasize themes from their blogs, websites and poems while considering how they can impact and improve public narratives.

The second portion of the analysis will build upon the narratives produced by young adults. I will discuss how youth feel the mainstream has represented their stories, life experiences and the impact it has had on their well-being. This will conclude the findings and analysis by outlining four suggestions for text literature producers to humanize young adults in their work. Future researchers, writers, journalists, among others can use the recommendations to ensure their publications are representing young adults in a way that is compassionate and accurate. It is important to note that these are simply suggestions, and they will not encompass every existent experience of parental incarceration due to the size of this study and the focus on postmodernism.

\section{Themes}

\section{\# 1: Comparative Narratives}

Three themes are prevalent among narrative writing collected from text-based literature. Despite attempts to balance negative and positive narratives, the findings revealed a substantial amount of pessimistic content. The first notable theme of interest within the narratives is 
comparative research and writing. Comparative research is when researchers create a prominent dichotomy between young adults with confined parents and young adults who have never experienced the incarceration of a parent (Eddy \& Poehlmann-Tynan, 2019). An example of this is the Muftić \& Smith (2018) study titled Sex, Parental Incarceration, and Violence Perpetuation Among a Sample of Young Adults.

Their (2018) work hypothesized that when young adults with a long-standing history of parental incarceration are compared to the general population, they are more likely to perpetrate violence (Muftić \& Smith, 2018). They also speculated that even after controlling for other demographic factors such as; school attachment, delinquent peers, self-control, parental neglect, and violent socialization, that sexual and non-sexual violence could be predicted in young adults with incarcerated parents (Muftić \& Smith, 2018). The researchers were also curious to see if gender played a role in who was perpetuating violence against others (Muftić \& Smith, 2018). To obtain this information, they gathered self-reported data from 534 college students in the United States (Muftić \& Smith, 2018). Their findings revealed that 13.3\% of the survey participants had been impacted by parental incarceration.

Muftić \& Smith (2018) discovered that although other risk factors still played a significant role in violent perpetration, violent actions were more prominent for those with incarcerated parents. However, gender variance is visible and evident when tested as a potential factor. For female participants with imprisoned parents, gender was a predictor of violence before the age of 15, while males engaged in acts of violence after the age of 15 (Muftic \& Smith, 2018). In the limitations section of the research, Muftić and Smith (2018) admit that the generalizability of their study may be problematic. They also note limitations in the size of the 
research pool and the racial disparities in their survey for being highly comprised of Black females (Muftić \& Smith, 2018).

Although they admit to the limitations of their study, they fail to acknowledge them throughout the entirety of their research. There is no mention of intersectionality or the experience of over-policing in racialized communities. They attempt to defend this limitation by stating that although their study disproportionately relies on the narratives of Black females, their study is more diverse than the general state population (Muftic \& Smith, 2018). Instead of considering the impact of race, class, and politics in their work, they chose to simply compare those impacted by incarceration to those who were not (Eddy \& Poehlmann-Tynan, 2019). This comparison also is problematic, as only 71 of 534 respondents had dealt with parental confinement (Muftić \& Smith, 2018). The findings of increased violence from those with imprisoned parents may be purely coincidental as it is an extremely small sample size.

Using minimal data and generalized findings, the researchers attempt to create a clear distinction between young adults with and without incarcerated parents. Although it may not have been their intention, the narrative Muftic \& Smith (2018) have created through their comparison is that young adults with incarcerated parents are inherently more violent as a result of the experiences. This dichotomy narrative between those with and without confined parents can be harmful to young adults seeking a variety of professional supports. Studies such as this can contribute to mainstream academia, which may influence professionals entering the field to perceive this population as dangerous (Muftić \& Smith, 2018).

Muftic and Smith (2015) are not the only researchers that have subscribed to this narrative of a definitive divide separating young adults with incarcerated parents versus those without confined parents. This pattern is demonstrated throughout endless pieces of literature 
such as Heard-Garris et al., (2018) research Health Care Use and Health Behaviours Among Young Adults with a History of Parental Incarceration. I will discuss this paper again in the second theme. However, it is essential to note that the researchers in this study state "We hypothesized a priori that PI would be associated with lower levels of health care use and a higher prevalence of unhealthy behaviours compared with individuals without PI" (Heard-Garris et al., 2018, p.1). Their nationally representative study found a consistent link between parental confinement and health care access as well as unhealthy behaviours (Heard-Garris et al., 2018). One of their suggestions for gaining equal treatment within the health care system was for pediatric providers to conduct an evaluation to determine adverse life experience as a result of parental incarceration (Heard-Garris et al., 2018).

The researchers have already aided in producing a narrative that young adults with incarcerated parents should be compared to the general population in order to be researched sufficiently. Researchers and writers rarely study young adults with confined parents as a single entity. A variety of researchers, as stated in the literature, have observed that young adults with incarcerated parents can and do experience adverse experiences compared to other young adults (Eddy \& Poehlmann-Tynan, 2019). (Heard-Garris et al., 2018) have essentially suggested that medical professionals should inquire if young adults have incarcerated parents to ensure that they can limit barriers to health care. If young adults with confined parents are already experiencing less than adequate support medically, they then are expected to disclose their parental history to the professional, which could have the potential to stigmatize them further.

This narrative does not only occur in scholarly research; it is also a theme that finds its way into popular media. Journalist Resource is a newspaper for access to both journalists and the public in the hopes of bridging the gap between complicated academia/policy and journalism. In 
(2018) Journalist Resource published an article relaying the findings of the Heard-Garris (2018) study. I was curious to see if that same narrative produced in the study would vary when published in a news article, so I decided to track any language that indicated a distinction between the groups of youth. The terms I chose to record were "when compared", "more likely", "less likely" and "likelihood."

The term "when compared" appeared twice in the three-page article, "when compared" occurred two times, "more likely" five times, and "less likely" two times. Comparative terms saturate the piece, furthering the othering narrative that young adults with incarcerated parents can only be studied in "black and white" understandings. It is evident that when the textual media attempts to simplify jargon-filled professional knowledge for other journalists and the general population, they still subscribe to the idea that young adults without incarcerated parents are "the standard". Consistently positioning young adults without incarcerated parents as a completely separate entity than those with confined parents perhaps suggests that those with incarcerated parents should strive to be more like the other young adults. The concern is that without structural changes beyond young adults with incarcerated parents' control, meeting this "standard" is unobtainable.

In Murray and Farrington's (2008) essay, they were interested in observing the causal effect of parental incarceration on children of imprisoned parents. They wanted to consider these potential impacts during the period of imprisonment and in later life during adolescence and adulthood (Murray \& Farrington, 2008). To do so, they had first to determine if parental confinement shared a link to adverse childhood outcomes. To be considered for their analysis, they set requirements on literature used. They decreed that any content used "must include children of prisoners and at least one group of children without imprisoned parents (preferably 
drawn from the general population of the same age as the children of prisoners)"(Murray \& Farrington, 2008). They intended to set "minimum criteria" although they believed stricter prerequisites would have increased the validity of their essay (Murray \& Farrington, 2008). What the writers are implying is that without comparative measures, research reduces its legitimacy (Murray \& Farrington, 2008).

\section{\#2. Adverse Life Outcomes}

Through the examination of both scholarly research and text-based news media, another narrative/theme arose. That narrative revolves around the conception that young adults with incarcerated parents experience primarily adverse life outcomes and circumstances. As previously mentioned, research and media can construct public belief and motivations (Happer \& Philo, 2013). Therefore, with both disproportionately reporting on the harsh but not inevitable implications of having an incarcerated parent, they can alter how society perceives these young adults. The most common consequences that literature attempts to attach to young adults with confined parents are regarding their social, psychological, and physical well-being.

I chose to examine these three particular negative themes because they occurred most frequently in the observed textual content. For the sake of critical reflexive analysis, social outcomes will refer to; anti-social mannerisms/friendships, stigma/discrimination, perpetuating violence, and criminal activity. Psychological outcomes will include texts on the impacts of parental confinement on young adults' mental health. Physical outcomes will describe the content in textual research and media aimed at the physical health implications of having an incarcerated parent at points throughout their lives. I will begin with social outcomes as they represent the majority of existing literature and are also the repercussions I experience most frequently. 


\section{Social Outcomes}

Finding text-based narratives regarding the social outcomes for young adults with incarcerated parents was exceptionally easy. The most prominent and prevailing story amongst the content I analyzed was that parental confinement is a determinant for the future incarceration/criminal justice interaction of young adults. This written portrayal of young adults initially appeared in Huebner \& Gustafson's (2007) analysis of literature regarding the relationship between maternal confinement and adult offspring's interaction with the criminal justice system. Through their review, they proclaimed that their findings were consistent with past research and that, despite testing for the variables such as maternal absence, a mother's incarceration had "direct effect of incarceration on adult offspring involvement in the criminal justice system" (Huebner \& Gustafson, 2007, p. 283). Although they were unable to demonstrate that maternal confinement was equated to criminal behaviours, they still associated the young adults with the narrative of cynical life outcomes.

Maternal incarceration has been discerned in several studies as more impactful on social consequences for children and young adults than that of paternal confinement. The majority of textual data works from the perception that the onus is on maternal confinement and that it has more dire impacts on influencing the future incarceration of their young adult children. In Dallaire's (2007) work, she analyzed an evaluation of 6,146 prisoners who participated in the U.S. Department of Justice Survey of Inmates in State and Federal Correctional Facilities. From this, she vocalized that there is a "predictive power" that mothers were "2.5 times more likely to report adult children who are incarcerated" (Dallaire, 2007, p.1). Mothers living with addictions or regular drug use before lockup are also determined to intensify the likelihood of incarceration for their young adult children (Dallaire, 2007). Dallaire (2007) concluded that maternal confinement 
and drug use were intergenerational and that they should deploy tactics of intervention to prevent future incarceration of their children.

This textual narrative emerged again in the language utilized in The Chronicle's (2019) article Children face lifelong struggles if their parents are incarcerated, study details. The publication relays to the general public through comparative language the notion that those young adults with imprisoned parents are inclined to adverse social outcomes. They write that in later in life, young adults are $3 x$ more likely to be convicted of a felony, 5x more likely to experience teen pregnancy and 6x more likely to use substances (Carlisle \& Costley, 2019). The authors also emphasized that half of the young adults with confined parents experience social stigma, which makes the transition into adulthood harder and can lead to anti-social behaviours (Carlisle \& Costley, 2019). Describing young adults through the lens of anti-social outcomes is not unique to this text article.

Eddy and Reid's (2001) research overviews the connection between parental incarceration and anti-social behaviours in adolescents. They claim that these anti-social traits are among the most reliable predictors for adult adjustment issues and illegal actions. The researchers recognize anti-social mannerisms as; "disobedience, aggression, temper tantrums, lying, stealing and violence" (Eddy \& Reid, 2001, p. 2). They indicate through their language that "anti-social behaviour can gain momentum even before birth and then increase in velocity and intensity through successive, cascading antecedents during childhood and adolescence" (Eddy \& Reid, 2001, p. 6). Writing that anti-social behaviour can begin before birth essentially indicates that these outcomes are beyond the child's control unless they have significant familial support. What this relays to researchers and the public is that little can be done through the implementations of 
supports and services and that the responsibility for later life outcomes is primarily dependent on the child's family.

The concept of being socially labelled as a predetermined troublemaker is also a familiar narrative for young adults with incarcerated parents. Finkeldey et al. (2020) research utilizes language within their title that contributes to this message. The study is titled Identifying as a Troublemaker/Partier: The Influence of Parental Incarceration and Emotional

Independence which presents the idea that young adults with confined parents independently identify as troublemakers or partiers. The researchers found that "Parental incarceration was only positively associated with identifying as a troublemaker/partier during young adulthood among those with low emotional independence" (Finkeldey et al., 2020). To be recognized as "emotionally independent" the young adults should have separate beliefs and values from those of their parent (Finkeldey et al., 2020). This not only implies that incarcerated parents have negative beliefs and values, but it also means that young adults are destined for "troublemaking" if they are similar to their parent.

\section{Psychological \& Physical Outcomes}

The adverse life outcomes produced in textual literature are not restricted to social implications. This narrative has also trickled into the field of health care and mental health, to demonstrate that young adults with incarcerated parents have a predisposition for adverse health risks. Although this narrative arose through the initial literature review, an article I chose to highlight is a news article published by Reuters (2019). The report states to the public that the children of incarcerated parents are "at risk for lasting psychiatric problems" (Rapaport, 2019, p.1). The author outlined many psychiatric concerns that were associated with parental confinement including; depression, substance use, social isolation, anxiety, attention problems 
and disorders (Rapaport, 2019). Despite the author outlining that the study believed other factors could impact the health outcomes in early adulthood, they only wrote about these factors concerning confinement and not as a separate entity (Rapaport, 2019).

Individuals who do not search for the full study and only rely on text media for their information remain with the impression that in early adulthood, mental-health outcomes will always be a "risk". This anticipation or expectation of risks became apparent during my undergraduate when I disclosed to a professor that my father was incarcerated. Their response was "well you seem to be doing well in school in spite of." To me, this relayed the idea that I was supposed to be exhibiting certain behaviours to demonstrate that I had a confined parent. Adverse physical health outcomes have also become a subject of interest for researchers; however, even though they have attempted to understand and potentially solve these health risks, they continue to focus on outcomes without a solution. Researchers and news/media organizations alike have hinted at physical ailments such as; high cholesterol, HIV/AIDS, migraines, breathing difficulties (asthma), and obesity (specifically in females) (Roettger \& Boardman, 2012; Lee et al., 2013).

If we as a population continue to ingest biased and limited textual research and media content, we are putting these young adults in more danger than just anticipated social or health outcomes. If our understanding of these adults is that they are predetermined "spoiled goods", this can influence public policy because we believe that no services can overcome these adverse outcomes (Sullivan, 2015). As a result, services are cut and instead of being focused on direct and immediate programming (such as daycare and safe and stable housing during the period of incarceration), they attempt to mediate assumed consequences (Sullivan, 2015). It is essential to understand that the statistics utilized by those producing textual literature are often not 
comprehensive enough and can rely on inaccurate and stigmatizing data (Sullivan, 2015). We must instead focus on the stories of the young adults impacted by parental incarceration and other social factors they articulate, such as racism, poverty, and unemployment (Sullivan, 2015).

\section{\#3. Conflicting Supports}

The final theme I will touch on can also often be found within literature, which is the conflicting need for support. What I mean by this is that the narrative produced by prevailing information sources is that young adults must receive help to break the impacts of adverse life outcomes. Through my analysis, I discovered that some researchers claim supports must come from the greater society in the form of; peer support, economic support, prison abolition, less policing in racialized communities, and counselling. (Siennick, 2014). Others believe that jails and prisons should engage in supporting their prisoners and their adult children through; parenting classes, better visitation policies within the prison, reduction in phone call cost within facilities, and ensuring parents remain close to their families to allow for more frequent visits (Barr et al., 2011). Some theorize that families should be the ones to ensure the wellbeing of young adults with incarcerated parents through; housing, economic needs, and emotional support (Dallaire, 2007). If these children are unable to access support through their family (immediate or extended), they can help themselves through internal resiliency and strength (Kjellstrand et al., 2018; Luther, 2016).

Researchers, journalists, and professional actively engaged in working with these young adults cannot agree on what programming should look like. Therefore, it is challenging to actually implement any substantial supports or resources. It is necessary for interdisciplinary discussions to occur for multiple services to communicate what needs and programming they witness a necessity for in their everyday work. Young adults are rarely included in the process of 
creating or altering services, potentially causing a larger conflict on what resources they might require. In addition, the "need" for supports suggests that young adults are incapable of succeeding in life without some form of intervention when in some instances young adults are solely relying on themselves.

\section{Recommendations \& Humanizing}

With the findings from textual research and media outlets, it is necessary to provide potential solutions with consideration to young adults with incarcerated parents' narratives. These recommendations are not a one-size-fits-all solution to addressing negative representation in textual data, and the scope of this research is unable to determine all possible avenues for support. These recommendations intend to provide future researchers, journalists and writers with concrete ways to alter the way they represent this community and remind readers to be cognizant of the content they are consuming. At the current time, the narrative created and maintained by the Global North far surpasses the amount of existing individual narrative literature from young adults, especially those from across the globe. Therefore, it is vital to remember that many stories are still untold and that we, as consumers of literature, media, articles, and other forms of text should continue to explore and encourage the inclusion of more narratives in understanding this multifaceted population.

As a result of continually being researched and identified as "subjects," we are often seen as numbers and dehumanized in the process of understanding us. The lack of overall literature on the children of incarcerated parents demonstrates that we are not a population of importance even though more than 10.35 million people were confined worldwide in 2016, many with children (Walmsley, 2016). When the textual research, writing and media does acknowledge our community, we are usually discussed in comparison as the "other", or predicting/stating adverse 
life outcomes (Sullivan, 2016). What textual data tends to miss is that this population is a group of unique, complex, and dynamic beings who identify in a multitude of ways through their own stories. With narratives retrieved through; blogs, news articles, research, and magazines, among others, we can humanize our experiences through the conveying of information.

\section{\#1a.) Inclusion}

If you are a researcher or a journalist writing about young adults with incarcerated parents and are not part of this community, include these young adults in your writing process. Although the researcher and journalist can never be fully removed or objective in their work, it is the voices of those impacted that establish meaning (Court \& Abbas, 2013). No single individual affected by parental confinement represents the entirety of the experience, but we deserve to be included in the research and not only as participants. We have made it into young adulthood; we are equipped with survival skills that we can pass on to those who follow in our footsteps, and you can provide us with the platform to do so (Elizabeth Fry Society of Greater Vancouver, 2019). Professor Sullivan from the University of Boston occupies a dual role as a researcher and as someone impacted by parental incarceration. Her narrative advocates for the inclusion of lived experience, particularly in textual data; "At a certain point I realized that I had to be part of the solution - or at least I owed it to others to use the knowledge I had to try to move the conversation forward" (Sullivan, 2016, p.1).

\section{\#1b.) Learning \& Relearning}

Although it is necessary to begin including those impacted by this social phenomenon, it is not our responsibility to serve as educators. Many lived experiences are rooted in stigma, grief and trauma, and this is not an interest we can remove ourselves from; it is our lives (Saunders, 2018). It is difficult for young adults to trust and be retraumatized by strangers readily; as 20- 
year-old Patricia who was impacted by the loss of her father on death row said: "It's just like you don't know who you can trust. You don't know who you can actually really go and talk to about your feelings 'cause there is really nobody" (Beck \& Jones, 2008, p.211). For researchers and journalists alike, it is relatively easy to find access to materials that can provide knowledge and clarification regarding young adults with incarcerated parents. Producers of literature scholarly and non-scholarly have a responsibility to learn and continuously learn about this population while remaining cognizant that no amount of learning makes them "experts."

For researchers, writers, media, among others "learning" is not enough; the process of unlearning is equally valuable. Teen Vogue (2017) published an article that included textual narratives from young adults across the United States. One young adult interviewed named Akiya McKnight, said that authority figures tend to discriminate against children of confined parents (Anspach, 2017). These figures (such as researchers and media) "automatically assume that, this kid is black, and they're from the 'hood, so they're acting out because they're bad," (Anspach, 2017, p.1). McKnight continued saying "They're not thinking that this kid is also still a child that needs love and doesn't know how to respond to the trauma that they're going through" (Anspach, 2017, p.1).

Sullivan (2015) writes "because the prison population in this country is, increasingly, poor and black, there is also a misperception that wealthier communities and different ethnicities are not touched by incarceration" (p.1). This misconception is just one of many examples of how researchers, writers, media, and others might conceptualize and stigmatize young adults with incarcerated parents without questioning where this notion stems from. Without an active process of unlearning, statistics become a reality, and these inaccurate perceptions can continue to the public. Researchers must draw on the reflexive-self to move beyond self-reflection when 
working with young adults with incarcerated parents. In the creation of knowledge, individuals must consider that what they know about this population is constructed and maintained through their interaction with the world, and it must be interrogated (Witkin, 2012).

\section{\#1c.) Focus on our Achievements and Supporting of Others}

Among the most prominent coping mechanisms that emerged from the narratives of ten young adults in Johnson and Easterling's (2014) study was helping others. As the findings of this study indicate when writers include young adults within their work, it primarily revolves around negative themes. Young adults' narratives tend to emphasize that popular textual writing often ignores our positive contributions to society. Four of the ten young adults involved in the (2014) research interviews stated that they drew personal strength from helping others (Johnson \& Easterling, 2014). A participant named Jordan noted that he enjoyed rapping and wanted to support other youth through this artistic outlet, in addition to serving his country (Johnson \& Easterling, 2014). Two other young adults named Jasmine and Kayla were interested in helping children through the medical field (Johnson and Easterling, 2014).

The mission to provide support to others is not restricted to the narratives included in this study; many young adults have achieved success through their work with others. Only two organizations in Canada are aimed at meeting the unique needs of individuals with confined parents, one example is Blue Sky Summer Camp. This 15-week, overnight summer camp is funded by the Elizabeth Fry Society of Vancouver and allows children between the ages of 6 and 15 to develop skills in coping, leadership, conflict, and conflict management (Elizabeth Fry Society of Vancouver, 2020). Once participants age out of camp, Elizabeth Fry offers them volunteer and job training to not only allow them to develop job experience and income but to encourage them to give back and be positive role models. Unfortunately, there were no personal 
narratives from the young adults, but I was able to gather stories from another agency based in the United States.

Project Avary, a year-round emotional support program, which makes a ten-year commitment to any child impacted by parental confinement (Project Avary, 2020). For this program to be possible, it relies heavily on young adults who have graduated the program, approximately $40 \%$ of all their staff are former Project Avary graduates (Project Avary, 2020). Among the fantastic volunteers is Project Avary Teen Leader and Junior Counsellor Ziri, who was 17 at the time of her interview and she was heading to college and was eager to become a social worker (Project Avary, 2018). With her social work diploma, she wanted to "return the gift" of accessing Project Avary by working for the organization with the intention of "breaking the cycle" (Project Avary, 2017, p.1).

Daughters Beyond Incarceration was founded by two women named Dominque Jones and Bree Anderson who both grew up with confined fathers. Their struggle with building and maintaining connections with their fathers inspired them to cultivate positive relationships for young Black females through programming aimed at communication, teamwork and passion (Daughters Beyond Incarceration, 2020). Daughters Beyond Incarceration foster this through matching girls with a mentor who has experienced the incarceration of their father and providing; self-awareness training, college tours, nutrition/cooking classes, financial literacy programming, prison visits, father and daughter bonding workshops, conflict resolution/problem solving, among many other (Daughters Beyond Incarceration, 2020).

Alongside her work as the Executive Director of Daughters Beyond Incarceration, Jones also speaks on several panels as a trauma expert concerning parental incarceration (Daughters Beyond Incarceration, 2020). Among her many credentials, she is also a published author in 
Loyola's Law Review in addition to having an undergraduate degree from Alabama State University and a Masters in Human Resource Education (Daughters Beyond Incarceration, 2020). The cofounder, Anderson, who is also the Director of Operations, is well known for her advocacy, entrepreneurship and her expertise in trauma work (Daughters Beyond Incarceration, 2020). She has spoken on her experience and aided in changing public perception through panels, talk shows, textual media/news and podcasts (Daughters Beyond Incarceration, 2020). Anderson has also tackled race-based discrimination as a former member of the National Association of the Advancement of Coloured People and a current member of Innocence Project New Orleans Young Professional Committee (Daughters Beyond Incarceration, 2020).

It is essential to consider that the majority of helping young adults provide is not seen or taken into consideration because it is through informal actions. For example, when Canadian mothers experience incarceration, many teens and young adults choose to cope by taking on roles in their household prematurely (Cunningham \& Baker, 2004). They may begin to engage in physical and emotional caretaking for their siblings, family members, and even their mother (Cunningham \& Baker, 2004). These caretaking activities place significant responsibility on a young adult, sometimes sacrificing their goals and opportunities in exchange for the wellbeing of those they love. These young adults may never have articles dedicated to them, awards, or even a thank you, but these accomplishments are mentionable none the less.

Through simple searches for resources (such as programming for those touched by parental incarceration) an overwhelming amount of content emerged. The young adults in Johnson and Easterling's (2014) work and those involved in Camp Blue Sky, Avary Project and Daughters Beyond Incarceration are just a few of the thousands of amazing individuals impacted but not defined by their parent's confinement. Narratives produced by those outside the 
community need to acknowledge that despite the hardships we may face, we are also achieving greatness and supporting others in their greatness. Instead of continually fixating on the negative narratives can be altered if those creating literature spend time exploring and writing textual pieces regarding the hard work and dedication of young adults. These changes may seem insignificant, but they may be some individuals' first interaction with this population, or even make people rethink what they believe they know about young adults with confined parents.

\section{\#1d.) Be Sensitive}

I am explicitly targeting this particular recommendation at the producers of text media, but it still serves as a critical reminder to researchers. When you report about crimes, deaths, and trials, the press often arrives and receives information before families do. For victims of crime (including young adults), how you relay information and the language you use may be the first we hear of potentially life-altering news. Also, many of the young adults affected live in the communities where these events have taken place; therefore, the language you use and the information you convey to the public can be stigmatizing and can further disenfranchise grief (Beck \& Jones, 2008). Returning to the recommendation of humanizing young adults with confined parents, consider how you would want to receive difficult news.

In one instance, when my father was arrested my method of finding out was to search online for details. Mitchell (2011) wrote an article regarding my father's sentencing, the language which he included still resonates with me years later "Mr. $* * * *$ is an unrepentant, unremorseful scourge on the community" (p.1). The language used in this article left me feeling humiliated, and with shared last names, I always felt fearful that someone would connect me to him and associated me with these traits. I am among many young adults who have been impacted by the media's representation of their parent; however, my experience has been far more privileged than 
many. In Beck and Jones's (2008) study of children with parents on death row in the United States, many of the young adults stated that the media had a significant impact on their experience. Death row cases often have profound amounts of media attention, and despite a child's effort to disassociate from the public eye, they are often implicated regardless.

One of their participants in Beck and Jones's (2008) interviews named Teresa returned to school a week later following her father's highly publicized execution. To her surprise, other students knew about the case and began to make fun of her "behind her back". Another individual named Victor stated that he was not allowed to grieve the loss of his father due to the stigma he experienced from his community as a result of publicly accessible information. His father set a fire that killed his mother, two younger sisters and a neighbourhood child. After this knowledge became public, people in his community would say things that forced Victor to protect his grandmother, such as "That's the mother of the baby killer!" (Jones \& Beck, 2008, p. 205). Victor claimed that public perception of his father forced him to choose between grieving for his family or his father (Jones \& Beck, 2008, p. 206).

Although Johnston and Sullivan's (2016) work discusses visual media, it still holds validity on how the news impacts those with incarcerated parents. One young adult named Sharika stated that before heading to school, she was watching the news and overheard her father's name on the television (Johnston \& Sullivan, 2016). Through this, she and her mother discovered that the police department had shot her father and that he was now in prison (Johnston \& Sullivan, 2016). No information reached Sharika and her family regarding her father and his injuries before the media disclosed this information to the public. The press must remain cognizant of the detrimental role they play in people's lives and how their language and stories can alter public perception and overall safety for young adults. 


\section{Chapter 6. Implications}

\section{COVID-19}

Narrative inquiry holds great importance for young adults with incarcerated parents; it allows them to express and share their understanding of their experience authentically. It also promotes the value of community stories which can be vital in a population that is silenced and separated due to stigma. I intended to do in-person interviews that were to be 90 minutes in length and would encourage the young adults to speak to, and in their own words describe their involvement with parental incarceration. The prompt questions in the interview would also ask young adults to describe how they perceive themselves in relation to the imprisonment and how they believe others see them. Unfortunately, in late 2019 and early 2020, a worldwide pandemic identified as COVID-19 has impacted the way people around the world go through their everyday lives. The National Center for Immunization and Respiratory Diseases [NCIRD], 2020) has asked individuals to social distance and self-isolate, preventing in-person interviews from taking place.

The opportunity to conduct interviews through programs such as Skype and Zoom was available to me as a researcher. However, given the sensitivity and nature of the narratives, it felt impersonal and less secure. For myself talking face to face with a participant often feels more natural and less formal. I believe it allows both myself and the young adult to gauge each other's body language; it avoids the potential for slow internet and other individuals listening in while also permitting those without internet access or computers to engage. I want to ensure that when telling the stories of my community, I am providing justice to their words, and without this direct contact I do not believe I would be doing so.

\section{Personal Inclusion}


One critique I repeatedly received during my writing process was my unwillingness to make this paper an autoethnography. An autoethnography is a form of qualitative research that is similar to critical reflexive analysis, but involves a significantly more in-depth revealing of my lived experience. I understand that this may limit my paper by removing a narrative that I can discuss fully and meaningfully. However, in a settler-colonial state "pain is more compelling than privilege" and it "is evidence of authenticity, of the verifiability of a lived life" (Tuck \& Yang, 2014, p. 229). I refuse to have my pain objectified to legitimize my story or "right" to discuss this topic.

Pain glorification is the same reason I choose to include more dynamic and positive representations of young adults with incarcerated parents. Their pain alone should not determine their merit for being involved in my research. A limitation of my study is that I could not fully remove pain as it is still an active piece of many experiences, and I refuse to silence those who express it. Also, I chose to limit my reflexive analysis to publicly available knowledge regarding my experience. Writing about my father's ongoing intersection with the criminal justice system puts him at potential legal risk.

\section{Self-Reflexivity/Intersectionality}

A significant limitation of this MRP is that it is a solo process based on my interpretations of existing textual content. As a result, I was unable to compare and contrast with a variety of individuals across disciplines to alter and expand on my social work lens. Also, I felt a disconnect from my community because I could not collaborate with and learn alongside them during this analysis. I am not the expert of text-based literature or the experience of parental incarceration, and I know others have so much to contribute to this conversation. Some of the articles used for recommendations did not explicitly state the young adult's race, gender, sexual 
orientation, ability, among other valuable identifiers. As a result, I cannot say with confidence that this critical reflexive analysis is as comprehensive or intersectional as I would like.

If granted the ability to create future research with these varying perspectives, I believe this study could serve as an excellent starting point for conversations regarding these young adults. Also, the inclusion of more narratives from young adults in the form of interviews would add an essence of depth to the suggestions on how to tackle narratives produced by those outside of the community. Instead of only providing suggestions to producers of dominant narratives as this paper does, the primary focus of future research could be recommendations from personalized worldviews. These stories could be reinforced using a secondary data analysis to highlight how interview stories and literature align. Until these gaps are met, this analysis should be used primarily to aid future researchers in prioritizing the words and experiences of young adults.

\section{Literature Limitations}

In the future I would like to build upon this analysis by incorporating different forms of media apart from strictly text-based online content. Apart from interviews as stated above, examining narratives produced in film, magazines, visual news, music, books, Facebook, Instagram, and Twitter, among others could highlight narratives that have yet to be explored in this study. I believe that collecting information from as many sources as possible could strengthen the argument that narratives produced in popular literature contribute to the profile of a deviant, and socially reclusive young adult with adverse life outcomes. Drawing from worldwide narratives could reveal universal themes that exist across cultural experiences and political climates. 


\section{Chapter 7. Conclusion}

Addressing how young adults experience parental incarceration while considering the implications of narratives produced by researchers, writers, journalists, among others allows us insight into a traditionally silenced population. Historically, these individuals have been represented through numbers while their humanity and emotions are deemed unimportant in contrast. This analysis is a critical stepping-stone in requesting for writers to push the stories that young adults are creating, while departing from the idea that young adults are deviant, and socially reclusive. The more we learn about this population and hear their direct words, the more information we have to create increasingly ethical research, change public policies and implement more comprehensive programming. These narratives can not only alter public discourse, but they can prevent future barriers for those in their childhood and teen years living with an incarcerated parent.

With the narratives provided by young adults online through online studies, websites, and blogs, I was unable to present a "solution" or a single "overarching" narrative. It is important to note that this was never the intention of this analysis, the mission was to expose and reconsider existing stories. I was however able to provide the suggestion of humanizing, broken into three sub-sections based on the variety of stories and themes provided by young adults. These sections consisted of; including young adults in the writing process, learning and relearning conceptions and misconceptions about this community, focusing on achievements and how they support others, as well as being sensitive in the language and information released through media to the public. Without consideration of young adults' narratives and recommendations, we must wonder who is this research really for? 


\section{References}

Andrews, D. A., Bonta, J., \& Wormith, J. S. (2011). The risk-need-responsivity (RNR) model: Does adding the good lives model contribute to effective crime prevention? Criminal Justice and Behavior, 38(7), 735-755. doi:10.1177/0093854811406356

Anspach, R. (2017). What it's like to grow up with a parent behind bars. Teen Vogue. https://www.teenvogue.com/story/what-its-like-to-have-an-incarcerated-parent

Arditti, J. A. (2005). Families and incarceration: An ecological approach. Families in Society: The Journal of Contemporary Social Services, 86(2), 251-260. doi:10.1606/10443894.2460

Arribas-Ayllon, M. \& Walkerdine, V. (2008). Foucauldian discourse analysis. In Willig, C., \& Stainton-Rogers, W. The SAGE handbook of qualitative research in psychology (pp. 91108). London: SAGE Publications Ltd doi: 10.4135/9781848607927

Bandura, A. (1977). Social learning theory. Englewood Cliffs, NJ: Prentice Hall.

Barnoff, L., \& Moffatt, K. (2007). Contradictory tensions in anti-oppression practice in feminist social services. Affilia, 22(1), 56-70. doi:10.1177/0886109906295772

Barr, R., Brito, N., Zocca, J., Reina, S., Rodriguez, J., \& Shauffer, C. (2011). The baby elmo program: Improving teen father-child interactions within juvenile justice facilities. Children and Youth Services Review, 33(9), 1555-1562. doi:10.1016/j.childyouth.2011.03.020

Baskin, C. (2016). Strong helpers' teachings: The value of indigenous knowledges in the helping professions (Second ed.) Canadian Scholars' Press.

Beck, A. T. (1976). Cognitive therapy and the emotional disorders. International Universities Press. 
Beck. A. T., Rush, A., \& Shaw, E. (1979). Cognitive therapy of depression. New York: Guilford Press.

Beck, E., \& Jones, S. J. (2008) Children of the condemned: Grieving the loss of a father to death row. OMEGA - Journal of Death and Dying, 56(2), 191-215. doi:10.2190/OM.56.2.d

Bernstein, N. (2005). All Alone in the World. New York, NY: New Press.

Bettencourt, A. (2019). Grassroots organizations are just as important as seed money for innovation. Medium. https://medium.com/unhcr-innovation-service/grassrootsorganizations-are-just-as-important-as-seed-money-for-innovation-53a8af9f7a78

Blix, B. H. (2015). Something decent to wear: Performances of being an insider and an outsider in indigenous research. Qualitative Inquiry, 21 (2), 175-183. doi:10.1177/1077800414542702

Bronfenbrenner, U. (1977). Toward an experimental ecology of human development. American Psychologist, 32(7), 513-531. doi:10.1037/0003-066X.32.7.513

Carlisle, P., Costley, A. (2019). Children face lifelong struggles if their parents are incarcerated, study details. University Wire

Carodet, R. (1992). Genetic and environmental factors in the transition to abuse. In M. Glantz \& R. W. Pickens (Eds.), Vulnerability to drug abuse (pp. 1131-1136). Washington, DC: American Psychological Association.

Charmaz, K. (2017). The power of constructivist grounded theory for critical inquiry. Qualitative Inquiry, 23(1), 34-45. doi:10.1177/1077800416657105

Clemens, T., Popham, F., \& Boyle, P. (2015). What is the effect of unemployment on all-cause mortality? A cohort study using propensity score matching. European Journal of Public 
Health, 25(1), 115-121. doi:10.1093/eurpub/cku136

Cochran, J. C., Siennick, S. E., \& Mears, D. P. (2018). Social exclusion and parental incarceration impacts on adolescents' networks and school engagement. Journal of Marriage and Family, 80(2), 478-498. doi:10.1111/jomf.12464

Connelly, F. M., \& Clandinin, D. J. (1990). Stories of experience and narrative inquiry. Educational Researcher, 19(5), 2-14. doi:10.3102/0013189X019005002

Coulthard, J. (2010). Parental incarceration and the ties that bind: children of offenders as collateral damage- unpublished doctoral dissertation, McGill University.

Court, D., \& Abbas, R. (2013). Whose interview is it, anyway? methodological and ethical challenges of Insider-Outsider research, multiple languages, and dual-researcher cooperation. Qualitative Inquiry, 19(6), 480-488. doi:10.1177/1077800413482102

Crenshaw, K. (1991). Mapping the margins: Intersectionality, identity politics, and violence against women of color. Stanford Law Review, 43(6), 1241-1299. doi:10.2307/1229039

Creswell, J. W. (2013). Qualitative inquiry \& research design: Choosing among five approaches (Third ed.) SAGE Publications.

Cunningham, A. H., Baker, L. L., \& Centre for Children \& Families in the Justice System. (2004). Waiting for mommy: Giving a voice to the hidden victims of imprisonment Centre for Children and Families in the Justice System.

Dallaire, D. H. (2007). Incarcerated mothers and fathers: A comparison of risks for children and families. Family Relations, 56(5), 440-453. doi:10.1111/j.1741-3729.2007.00472.x

Dallaire, D. H., Ciccone, A., \& Wilson, L. C. (2010). Teachers' experiences with and expectations of children with incarcerated parents. Journal of Applied Developmental Psychology, 31(4), 281-290. doi:10.1016/j.appdev.2010.04.001 
Daughters Beyond Incarceration. (2020). What we do - Daughters beyond incarceration. https://www.dbinola.org/what-we-do

DeLisi, M., \& Conis, P. J. (2018). Violent offenders: Theory, research, policy, and practice (Third ed.) Jones \& Bartlett Learning.

Denzin, N. K., \& Giardina, M. D. (2016). Qualitative inquiry through a critical lens Routledge. doi:10.4324/9781315545943

Dulmus, C. N., \& Sowers, K. M. (2012). The profession of social work. US: Wiley.

Durrant, R., \& Ward, T. (2015). Evolutionary criminology: Towards a comprehensive explanation of crime. US: Elsevier.

Eddy, J. M., \& Poehlmann-Tynan, J. (2019). Handbook on children with incarcerated parents: Research, policy, and practice (2nd;2; ed.). CH: Springer.

Eddy, J. M., \& Reid, J. B. (2001). The antisocial behavior of the adolescent children of incarcerated parents: A developmental perspective. ASPE. https://aspe.hhs.gov/basicreport/antisocial-behavior-adolescent-children-incarcerated-parents-developmentalperspective

Elizabeth Fry Society of Greater Vancouver. (2019). Supporting children with incarcerated parents. Elizabeth Fry. https://cjr.ufv.ca/wp-content/uploads/2019/01/SupportingChildren-with-incarcerated-parents.pdf

Elizabeth Fry Society of Greater Vancouver. (2020). Programs and services. Elizabeth Fry Society of Greater Vancouver. https://www.elizabethfry.com/we-can-help/programsservices/

Eriksson, M., Ghazinour, M., \& Hammarström, A. (2018). Different uses of Bronfenbrenner's ecological theory in public mental health research: What is their value for guiding public 
mental health policy and practice? Social Theory \& Health, 16(4), 414-433.

doi:http://dx.doi.org.ezproxy.lib.ryerson.ca/10.1057/s41285-018-0065-6

Faulkner, S. S., \& Faulkner, C. A. (2016). Research methods for social workers: A practicebased approach (2nd ed.). Oxford University Press.

Finkeldey, J. G., Longmore, M. A., Giordano, P. C., \& Manning, W. D. (2020). Identifying as a Troublemaker/Partier: The influence of parental incarceration and emotional independence. Journal of Child and Family Studies, 29(3), 802-816. doi:10.1007/s10826019-01561-y

Fook, J. (1999). Reflexivity as method. Annual Review of Health Social Science, 9(1), 11-20. doi:10.5172/hesr.1999.9.1.11

Foster, H., \& Hagan, J. (2015). Maternal and paternal imprisonment and children's social exclusion in young adulthood. The Journal of Criminal Law and Criminology (1973- ), 105(2), 387-429.

Hanington, D. (2020). From the inside out: Effects of parental incarceration on children. Canadian Journal of Family and Youth / Le Journal Canadien De Famille Et De La Jeunesse, 12(2), 36-47. doi:10.29173/cjfy29510

Happer, C., \& Philo, G. (2013). The role of the media in the construction of public belief and social change. Journal of Social and Political Psychology, 1(1), 321336. https://doi.org/10.5964/jspp.v1i1.96

Hardy, J. (2018). Parental Incarceration's effect on family: Effects on mothers, fathers, marriage, children, and socioeconomic status. Canadian Journal of Family and Youth / Le Journal Canadien De Famille Et De La Jeunesse, 10(1), 119-140. doi:10.29173/cjfy29345

Heard-Garris, N., Winkelman, T. N. A., Choi, H., Miller, A. K., Kan, K., Shlafer, R., \& 
Davis, M. M. (2018). Health care use and health behaviors among young adults with history of parental incarceration. Pediatrics, 142(3), e20174314. doi:10.1542/peds.2017-4314

Huebner, B. M., \& Gustafson, R. (2007). The effect of maternal incarceration on adult offspring involvement in the criminal justice system. Journal of Criminal Justice, 35(3), 283-296. doi:10.1016/j.jcrimjus.2007.03.005

James, N. (2018). Risk and needs assessment in the federal prison system. Congressional Research Services. https://justiceroundtable.org/wp-content/uploads/2018/07/Risk-andNeeds-Assessment-in-the-Federal.pdf

Johnson, E. I., \& Easterling, B. A. (2015). Coping with confinement: Adolescents' experiences with parental incarceration. Journal of Adolescent Research, 30(2), 244-267. doi:10.1177/0743558414558593

Johnston, D., \& Sullivan, M. (2016). Parental incarceration: Personal accounts and developmental impact. Routledge.

Kjellstrand, J., Yu, G., Eddy, J. M., \& Martinez, C. R. (2018). Children of incarcerated parents: Developmental trajectories of externalizing behavior across adolescence. Criminal Justice and Behavior, 45(11), 1742-1761. doi:10.1177/0093854818785400

Lam, C. M., Wong, H., \& Terry Tse Fong Leung. (2007;2005;). An unfinished reflexive journey: Social work students' reflection on their placement experiences. The British Journal of Social Work, 37(1), 91-105. doi:10.1093/bjsw/bcl320

Latimer, J., Foss, L. C., Canada. Department of Justice. Research and Statistics Division, \& Canada. Youth Justice Policy Section. (2004). A one-day snapshot of aboriginal youth in custody across Canada: Phase II Dept. of Justice Canada. 
Lee, R. D., Fang, X., \& Luo, F. (2013). The impact of parental incarceration on the physical and mental health of young adults. Pediatrics, 131(4), e1188-e1195. doi:10.1542/peds.20120627

Luther, K. (2016). Stigma management among children of incarcerated parents. Deviant Behavior, 37(11), 1264-1275. doi:10.1080/01639625.2016.1170551

Lynch, M. (2011). Crack pipes and policing: A case study of institutional racism and remedial action in Cleveland. Law \& Policy, 33(2), 179-214. doi:10.1111/j.14679930.2010.00334.x

Mayrl, D. (2013). Fields, logics, and social movements: Prison abolition and the social justice field. Sociological Inquiry, 83(2), 286-309. doi:10.1111/j.1475-682X.2012.00428.x

Miehls, D., \& Moffatt, K. (2000). Constructing social work identity based on the reflexive self. The British Journal of Social Work, 30(3), 339-348. doi:10.1093/bjsw/30.3.339

Mignon, S. I., \& Ransford, P. (2012). Mothers in prison: Maintaining connections with children. Social Work in Public Health: The Impact of Parental Incarceration on Children and Families, 27(1-2), 69-88. doi:10.1080/19371918.2012.630965

Miller, H. V., \& Barnes, J. C. (2015). The association between parental incarceration and health, education, and economic outcomes in young adulthood. American Journal of Criminal Justice, 40(4), 765-784. doi:10.1007/s12103-015-9288-4

Mitchell, J. (2011). 'Career criminal' gets five years for Durham thefts. DurhamRegion.com. https://www.durhamregion.com/news-story/3514420--careercriminal-gets-five-years-for-durham-thefts/

Mowen, T. J., \& Visher, C. A. (2016). Changing the ties that bind. Criminology \& Public Policy, 15(2), 503-528. doi:10.1111/1745-9133.12207 
Moffatt, K. J. (2019). Postmodern social work: Reflective practice and education. Columbia University Press.

Moffatt, K. (1999). The surveillance and governance of the welfare recipient. In A. Chambon,

A. Irving, \& L. Epstein (Eds.) Reading Foucault for social work (pp. 219-245). New

York: Columbia University Press.

Muftić, L. R., \& Smith, M. (2018). Sex, parental incarceration, and violence perpetration among a sample of young adults. Journal of Interpersonal Violence, 33(2), 316-338. doi:10.1177/0886260515605123

Murray, J., \& Farrington, D. (2008). The effects of parental imprisonment on children. Crime and Justice, 37(1), 133-206. doi:10.1086/520070

National Center for Immunization and Respiratory Diseases (NCIRD).(April, 2020). How to protect yourself and others. https://www.cdc.gov/coronavirus/2019-ncov/prevent-gettingsick/prevention.html

Neufeld, S. D., Chapman, J., Crier, N., Marsh, S., McLeod, J., \& Deane, L. A. (2019). Research 101: A process for developing local guidelines for ethical research in heavily researched communities. Harm Reduction Journal, 16(1), 41-11. doi:10.1186/s12954-019-0315-5

O'Hear, M. (2017). Wisconsin sentencing in the tough-on-crime era: How judges retained power and why mass incarceration happened anyway. Wisconsin: The University of Wisconsin Press.

Ossefort-Russell, C. (2018). Resilience: A new grief myth that can hurt you. Medium. https://medium.com/the-mission/resilience-a-new-grief-myth-that-can-hurtyou-40af29639e62

Parton, N. O., O’Byrne, P. (2000). Constructive social work: Towards a new practice. New 
York: St. Martin's Press

Phillips, S. D., \& O'Brien, P. (2012). Learning from the ground up: Responding to children affected by parental incarceration. Social Work in Public Health: The Impact of Parental Incarceration on Children and Families, 27(1-2), 29-44.

doi:10.1080/19371918.2012.629914

Pietroni, M. (1995). The nature and aims of professional education for social workers: A postmodern perspective. In M. Yelloly \& M. Henkel (Eds.), Learning and teaching in social work: Towards reflective practice (pp. 34-50) London: Jessica Kingsley.

Poehlmann, J. (2005). Incarcerated mother's contact with children's, perceived family relationship and depressive symptoms. Journal of Family Psychology, 19(3), 350.

Poehlmann-Tynan, J., Burnson, C., Runion, H., \& Weymouth, L. A. (2017). Attachment in young children with incarcerated fathers. Development and Psychopathology, 29(2), 389404. doi:10.1017/S0954579417000062

Project Avary. (2018, May 9). The Avary blog — Project Avary. The Avary Blog. https://www.projectavary.org./the-avary-blog

Rapaport, L. (2019). With parents in prison, kids at risk for lasting psychiatric problems. Reuters U.S. https://www.reuters.com/article/us-health-parenting-incarceration/with-parents-inprison-kids-at-risk-for-lasting-psychiatric-problems-idUSKCN1VQ2OA

Reichel, C. (2018). Parents in prison and the lasting health effects on children. Journalist's Resource. https://journalistsresource.org/studies/society/publichealth/parental-incarceration-health-research/

Roettger, M. E., \& Boardman, J. D. (2012). Parental incarceration and gender-based risks for increased body mass index: Evidence from the national longitudinal study of adolescent 
health in the united states. American Journal of Epidemiology, 175(7), 636-644. doi:10.1093/aje/kwr409

Saunders, V. (2018). What does your dad do for a living? Children of prisoners and their experiences of stigma. Children and Youth Services Review, 90, 21-

27. https://doi.org/10.1016/j.childyouth.2018.05.012

Schön, D. (1983). The reflective practitioner. New York: Basic Books.

Siennick, S. E. (2014). Parental incarceration and intergenerational transfers to young adults. Journal of Family Issues, 37(10), 1433-1457. doi:10.1177/0192513X14550366

Smith, A. J. (2017). An examination of the impact of demographic and correctional institutional factors on the psychosocial behaviours of young adults with incarcerated parents (10279766) (Doctoral dissertation). Retrieved from ProQuest Dissertations and Theses database. (10279766)

Sullivan, M. (2015). The long shadow cast by a parent's incarceration. WBUR. https://www.wbur.org/cognoscenti/2015/06/01/children-of-incarcerated-parentsmegan-sullivan

Sullivan, M. (2016). One professor's fight to help the children of incarcerated parents. Medium. https://medium.com/boston-university-pr/one-professors-fight-to-help-thechildren-of-incarcerated-parents-e71a220a0371

Tuck, E., \& Yang, K. W. (2014). R-words: Refusing research. In D. Paris \& M. T. Winn (Eds.), Humanizing research: Decolonizing qualitative inquiry with youth and communities (pp. 223-247). Los Angeles, CA: SAGE.

Tudge, J. R. H., Payir, A., Merçon-Vargas, E., Cao, H., Liang, Y., Li, J., \& O'Brien, L. (2016). Still misused after all these years? A reevaluation of the uses of bronfenbrenner's b 
ioecological theory of human development. Journal of Family Theory \& Review, 8(4), 427-445. doi:10.1111/jftr.12165

Turner, S. G. (2001). Resilience and social work practice: Three case studies. Families in Society: The Journal of Contemporary Social Services, 82(5), 441-448. doi:10.1606/1044-3894.176

Vartanian, T. P. (2011). Secondary data analysis Oxford University Press.

Walmsley, R. (2016). More than 10.35 million people are in prison around the world, new report shows. World prison brief | an online database comprising information on prisons and the use of imprisonment around theworld. https://www.prisonstudies.org/news/more1035-million-people-are-prison-around-world-new-report-shows

Warde, B. (2013). Black male disproportionality in the criminal justice systems of the USA, canada, and england: A comparative analysis of incarceration. Journal of African American Studies, 17(4), 461-479. doi:10.1007/s12111-012-9235-0

Witkin, S. L. (2012). Social construction and social work practice: Interpretations and innovations (1st ed.). Columbia University Press.

Yee, J. Y., \& Wagner, A. E. (2013). Is anti-oppression teaching in canadian social work classrooms a form of neo-liberalism? Social Work Education, 32(3), 331-348. doi:10.1080/02615479.2012.672557

Zhang, H. (2018). How 'anti-ing' becomes mastery: Moral subjectivities shaped through antioppressive practice. British Journal of Social Work, 48(1), 124-140. doi:10.1093/bjsw/bcx010 